\title{
The rock-cut tomb of Bolores (Torres Vedras): an interdisciplinary approach to understanding the social landscape of the Late Neolithic/Copper Age of the Iberian Peninsula
}

\author{
La tumba hipogea de Bolores (Torres Vedras): una aproximación interdisciplinar a la \\ comprensión del paisaje social del Neolítico Final/Edad del Cobre de la Península Ibérica
}

\author{
Katina T. Lillios (*) \\ Joe Alan Artz (*) \\ Anna J. Waterman (**) \\ Jennifer Mack (*)
}

\author{
Jonathan T. Thomas (*) \\ Leonel Trindade $(* * *)$ \\ Isabel Luna (****)
}

\begin{abstract}
To better understand the sociopolitical landscape of the Portuguese Estremadura during the Late Neolithic/Copper Age, interdisciplinary excavations were conducted at Bolores (Torres Vedras), in the Sizandro River Valley. Following a test season in 1986, a University of Iowa team conducted four campaigns between 2007 and 2012. Bolores is a rock-cut tomb used primarily between $2800-2600$ cal BC for the burial of adults, adolescents, and children $(\mathrm{MNI}=36)$. The architectural, material cultural, and bioarchaeological evidence suggests that Bolores housed the remains of a distinctive group of local individuals who marked their difference from other burial populations in the Sizandro and Estremadura through material culture and tomb architecture. Social differences were denoted spatially and through offerings of material goods. No social stratification is evident, however, that would suggest a state-level society: there are no wealthy child burials and no significant health or dietary disparities within this population or between it and others in the region.
\end{abstract}

(*) Department of Anthropology, University of Iowa. 114 Macbride Hall. Iowa City. Iowa 52242 USA.

E-mail: katina-lillios@uiowa.edu; joe-artz@uiowa.edu; jennifer-mack@uiowa.edu; jonathan-t-thomas@uiowa.edu

(**) Mount Mercy University, Department of Natural and Applied Sciences. 150 Basile Hall. Cedar Rapids. Iowa 52402 USA. E-mail: awaterman@mtmercy.edu

(***) Rua Capitão João Figueiroa Rego 5 r/c esq. 2560-313 Torres Vedras.Portugal.

(****) Museu Municipal Leonel Trindade. Praça 25 de Abril. 2560-286 Torres Vedras. Portugal.

E-mail: misabel.luna@gmail.com

Received: 7-II-2013; accepted: 03-VI-2013.

\section{RESUMEN}

Para comprender mejor el paisaje sociopolítico de la Extremadura portuguesa durante el Neolitico Final/Edad del Cobre se han llevado a cabo excavaciones interdisciplinares en Bolores (Torres Vedras), en el valle del río Sizandro. Tras una campaña de prueba en 1986, un equipo de la Universidad de Iowa realizó cuatro campañas entre 2007 y 2012. Bolores es una tumba hipogea que fue utilizada principalmente entre 2800 y $2600 \mathrm{cal}$ $B C E$ como enterramiento colectivo para adultos, adolescentes y niños $(N M I=36)$. Los datos arquitectónicos, bioarqueológicos y de cultura material analizados hasta la fecha sugieren que Bolores albergó los restos de un grupo social distintivo compuesto de individuos locales que marcaban sus diferencias con otras poblaciones funerarias del Sizandro y Extremadura portuguesa mediante la cultura material y la arquitectura funeraria. Las diferencias sociales en la población de Bolores fueron señaladas espacialmente y marcadas mediante las ofrendas de bienes materiales. Sin embargo, no se aprecia una estratificación social significativa que sugiera una sociedad de nivel estatal: no hay enterramientos infantiles ricos, ni disparidades en la salud o dieta de esta población funeraria o entre esta población y otras en la región de Torres Vedras.

Key words: Iberian Peninsula; Portugal; Mortuary Archaeology; Demography; Isotope Studies; Neolithic; Chalcolithic; GIS.

Palabras clave: Península Ibérica; Portugal, Arqueología de la Muerte; Demografía; Marcadores isotópicos de dieta y movilidad; Neolítico; Calcolítico; SIG. 


\section{INTRODUCTION}

Decades of archaeological research in the Sizandro River Valley have generated a rich historical record of settlements and mortuary sites dated to the Holocene, particularly the Late Neolithic/Copper Age (3500-2200 cal BC) (Kunst and Trindade 1990). These sites include the settlements of Fórnea, Pragança, Penedo (Spindler and Trindade 1970), and Zambujal (Sangmeister et al. 1969, 1970, 1971, 1974-1977), the rock-cut tomb of Cabeço da Arruda I (Ferreira and Trindade 1955), the mortuary cave of Cova da Moura (Belo et al. 1961; Spindler 1981), and the tholoi of Paimogo (Gallay et al. 1973) and Serra da Vila/Borracheira (Trindade and Ferreira 1963). The interdisciplinary excavations at Zambujal, including specialist work on the fauna, groundstone tools, botanical remains, metals, and ceramics (Sangmeister and Schubart 1981; Kunst and Uerpmann 1996, 2002; Uerpmann and Uerpmann 2003; Kunst 2007; Kunst and Lutz 2008), have been instrumental in elucidating the broader social and economic dynamics of the $4^{\text {th }}$ to $2^{\text {nd }}$ millennia cal BC in the Estremadura, which include political centralization, regional interactions, and social transformation. Geomorphological, palynological, and ostracological studies have provided key environmental benchmarks and evidence for human activities in the Sizandro (Hoffmann 1990; Hoffman and Schulz 1995).

Despite this sustained period of intensive research, many important questions remain unanswered. For example, is there any evidence for social stratification among the Sizandro population of the $3^{\text {rd }}$ or $2^{\text {nd }}$ millennia cal $\mathrm{BC}$ that would suggest state-level societies, as debated by some Spanish archaeologists for southern Spain (Lull 1983; Nocete 1989)? If not, how were human populations organized during this period of time, and how did they mark social differences? What role did demographic changes play during the emergence and transformation of complex societies in the Sizandro?

To address these questions and contribute to a better understanding of cultural change and social variability in late prehistoric Portugal, a longterm interdisciplinary project-The Sizandro-Alcabrichel Research Project (SARP) - was initiated in 2007 under the co-direction of Katina Lillios (University of Iowa) and Michael Kunst (DAI). Project members initiated systematic sur- vey, geoarchaeological studies, radiometric dating and artifact studies of known sites, and an array of osteological analyses of the ancient human population in the region (bone chemistry, refitting, dental morphology, etc.). As part of SARP, excavations at the rock-cut tomb of Bolores were carried out. Although published references to Bolores exist from the 19th century (Torres 1861: 23), archaeologists first became aware of Bolores in 1986, when testing was conducted and its Late Neolithic/Copper Age date determined through diagnostic material culture (Zilhão 1987; Kunst and Trindade 1990: 38-41, Plate $4-5)$. In 2007, our team initiated excavations, and four seasons were conducted $(2007,2008,2010$, and 2012). Preliminary results from 2007 and 2008 have been published (Lillios et al. 2010), as have some biarchaeological analyses (1) (Waterman and Horwath 2009) and material culture studies (Thomas 2011). With excavations complete, we present a summary of our results to date.

\section{GEOGRAPHIC CONTEXT}

Bolores is located within the parish of Sta. Maria do Castelo e S. Miguel, in the municipality of Torres Vedras, in the district of Lisbon (Fig. 1). The site is a small, arched-roof rock-cut tomb carved into an east-facing outcrop of sandstone and shale. Situated at an elevation of 37 $38.5 \mathrm{~m}$ above sea level, it overlooks a small valley that drains to the Sizandro River (Fig. 2). The current channel of the Sizandro is located $125 \mathrm{~m}$ north of the site, and it flows to the Atlantic, $15 \mathrm{~km}$ to the west. With the exception of a marine limestone stratum, $200 \mathrm{~m}$ south, the outcrop at Bolores exposes interbedded sandstones and shales of late Jurassic age that were deposited in a terrestrial, deltaic environment (Anonymous 1992). At the site, the outcrop is dominated by a $3 \mathrm{~m}$ thick channel facies of sandstone, into which the arched and back-sloping roof of the cave was cut by people in the Late Neolithic/ Copper Age. They also excavated downward through harder sandstone, $30 \mathrm{~cm}$ thick, into a

(1) Waterman, A. J. 2012: Marked in Life and Death: Identifying Biological Markers of Social Differentiation in Late Prehistoric Portugal. Doctoral Dissertation.Department of Anthropology, University of Iowa. Iowa City. 


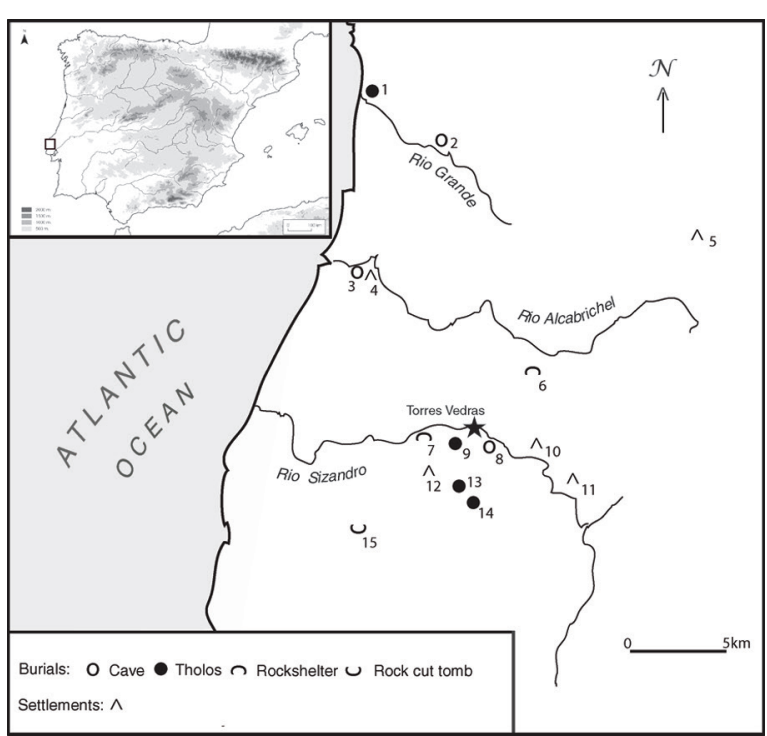

Fig. 1. Location of the rock-cut tomb of Bolores (Torres Vedras) in the Iberian Peninsula, and in the context of contemporary burial sites in the region. 1. Pai Mogo; 2. Feteira; 3. Lapa da Rainha; 4. Pico Agudo; 5. Pragança; 6. Algar do Bom Santo; 7. Bolores; 8. Cova da Moura; 9. Charrinho; 10. Fórnea; 11. Penedo; 12. Zambujal; 13. Serra da Vila; 14. Barro; 15. Cabeço da Arruda (Anna Waterman).

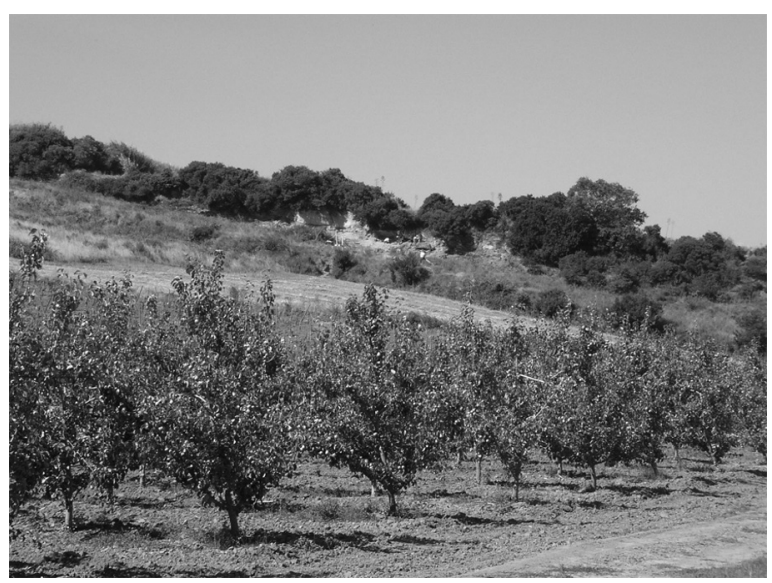

Fig. 2. The rock-cut tomb of Bolores (Torres Vedras), view toward west (2007) (Katina Lillios).

relatively thick shale unit that forms the floor of the site.

Although recent landscape changes in the area can be documented through photographs, these are only the most recent in a long history of environmental transformations. The most profound of these was related to postglacial eustatic sea rise. The result was flooding of the lower reaches of river valleys all along the Atlantic coast of the Iberian Peninsula, beginning about $12,000 \mathrm{cal}$ $\mathrm{BC}$, and reaching its maximum $c a .7000 \mathrm{cal} \mathrm{BC}$ (Zazo et al. 1996; Dabrio et al. 1999; Dabrio et al. 2000; Dias et al. 2000; Vis et al. 2008). This marine transgression created an estuary that extended an estimated $18 \mathrm{~km}$ up the Sizandro valley from the sea (Hoffman 1990; Dambeck et al. 2010). Between 7000 and 5000 BP, the coastal estuaries rapidly filled with alluvium (Vis et al. 2008). By ca. 6500 BP, the Sizandro estuary had become brackish (Lord et al. 2010). During the Late Neolithic/Copper Age (ca. 2800 cal BC), when Zambujal was occupied and Bolores was in use, the estuary extended only $10 \mathrm{~km}$ from the coast. The river valleys as well as the estuary also rapidly aggraded. The brackish water sediments studied by Lord et al. (2010) are buried under 17 $\mathrm{m}$ of alluvium. A soil boring on the Ribeira de Pedrulhos, about $2 \mathrm{~km}$ from Bolores, encountered a bone beneath $12 \mathrm{~m}$ of alluvium dated to 29102755 cal BC (Dambeck et al. 2010). This date is contemporary with dates from Zambujal and Bolores and indicates that local topographic relief during these sites' use was significantly greater than at present.

The same change in topographic relief occurred near Bolores. Soil borings by Artz in 2007 encountered 3-4 $\mathrm{m}$ of fluvially deposited sediment over bedrock in the small valley below. The site, presently 7-8 $\mathrm{m}$ above the valley floor, has in the past been up to $10 \mathrm{~m}$ higher than the valley bottom. Based on sedimentological and stratigraphic evidence, Dambeck et al. (2010) conclude that the rapid and thick accumulation of valley fills in the Sizandro and its tributaries was a consequence of increased soil erosion that accompanied the beginnings of intensive agriculture. Evidence for extreme erosion of uplands was encountered at Bolores in the form of water-transported mudclasts in colluvium that filled the cave after its abandonment (Lillios et al. 2010). The clasts exhibit the pedologic characteristics of angular blocky to subangular blocky B-horizons, and could only have entered the cave by being washed into it from above. During the 2012 season, we determined that, because of their association, the deposition of these mudclasts, as well as mudflows of similar material, began during or just after the final burials had occurred. As such, it appears that by this time, erosion had 
stripped away topsoil from the ridgetop above the site and had begun to cut into the subsoil horizons.

\section{PROJECT GOALS AND METHODS}

In addition to contributing to an understanding of the landscape dynamics of the Sizandro River Valley, our research at Bolores has sought to address basic questions regarding the chronology and use of space from a fine-grained microhistorical perspective as well as to engage in broader debates concerning the social lives of people who lived in the Iberian Peninsula during the $3^{\text {rd }}$ millennium cal BC. Among the site-specific questions, we aimed to assess taphonomic processes and the relative role of cultural and natural factors in shaping the archaeological deposits. Because it was evident that Bolores was carved out of a sandstone lithology that weathers easily and has undergone dynamic changes, we have also aimed to understand the tomb's original morphology. The human population at the site was a major concern, and we have worked to derive as complete a picture as possible of the liveways and deathways of these individuals and to compare these to other burial populations in the Sizandro and Estremadura. In addition to these site-specific questions, we have also been concerned with evaluating the evidence for social stratification among the Sizandro population of the $3^{\text {rd }}$ and $2^{\text {nd }}$ millennia cal $\mathrm{BC}$ that would suggest the level of state-level societies. Additional questions we have asked include: What role did demographic changes play during the emergence and transformation of complex societies in the Sizandro? How did socioeconomic changes impact human health and diet? How did changes in mortuary practices, from caves and rockshelters to rock-cut tombs and tholoi, reflect as well as shape social life? And finally, what role did ecological changes have on the social history of populations in the region?

To address these questions, we excavated as much of the site as possible and used comparable methods each season. Eighteen 1 x 1 m units were opened, and over $80 \%$ of the site's deposits were excavated (Fig. 3). Some areas were left unexcavated because they were supporting unstable stone overburden. Recovered bones and artifacts were photographed in situ, labeled on pho- tographs printed on-site, and mapped with a total station before being removed and individually recorded in the field catalogue. Approximately 5700 human bone and tooth specimens were recovered from all seasons. Over $65 \%$ of these were point-plotted in situ with a total station. The remaining $35 \%$ were provenienced by unit and level.

All remains were transported for study to the University of Iowa Department of Anthropology. Skeletal and dental materials were identified by

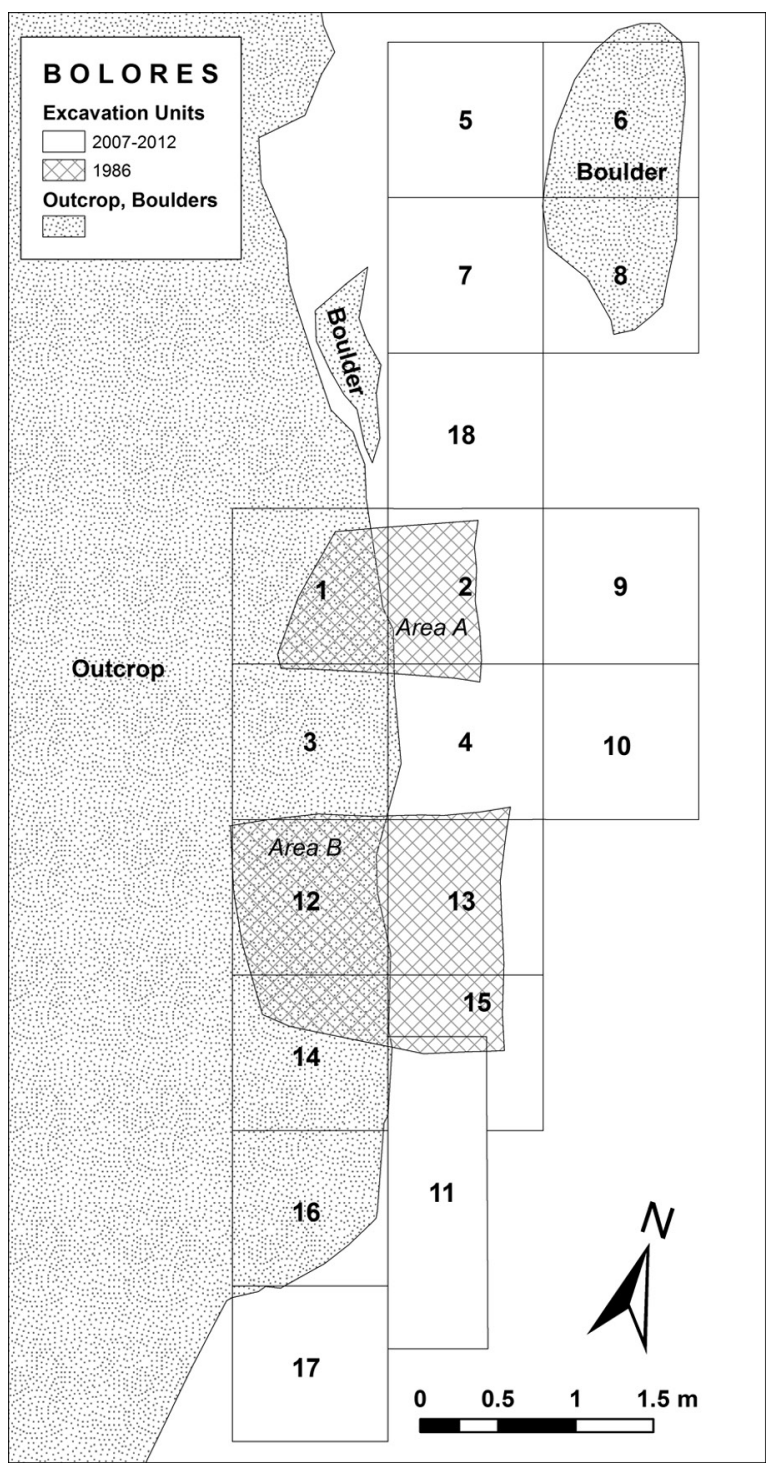

Fig. 3. Plan of the rock-cut tomb of Bolores (Torres Vedras), showing units excavated through 2012 (Joe Alan Artz). 
criteria outlined in standard osteological texts (Scheuer and Black 2000; White 2000; Baker et al. 2005) and through comparison with the University of Iowa Department of Anatomy's skeletal collection. All bones were coded to body region, element, portion (e.g. upper limb, humerus, distal end), and landmarks for determination of MNE (minimum number of elements), MNI, and taphonomic studies (underway). The minimum number of individuals (MNI) reported on here was calculated by counting duplicate tooth types, specifically, ULI1s (upper left first incisors) and LRdm1s (lower right deciduous first molars), which are morphologically distinctive. This method was chosen because of the high level of fragmentation of the remains.

Subadult age-at-death was calculated by epiphyseal fusion, diaphyseal length, or dental development (Schour and Massler 1941; Smith 1991; Scheuer and Black 2000; Baker et al. 2005; AlQahtani et al. 2010). Because the remains are highly fragmented, adult age-at-death estimates are difficult and could not be calculated by the degree of cranial suture fusion (Todd and Lyon 1925a, 1925b, 1925c; (2); Meindl and Lovejoy 1985; Mann et al. 1987), the morphological changes in the auricular surface of the os coxae (Lovejoy et al. 1985; Meindl and Lovejoy 1989; Ubelaker 1999) or the pubic symphysis (Todd 1920, 1921; Brooks and Suchey 1990). In instances where partial or complete mandibles with in situ molars were recovered, occlusal wear patterns were used to estimate age-at-death ranges. These were calculated based on the scoring of molar wear as outlined in Brothwell (1981). Ageat-death estimation using occlusal wear is based on the premise that teeth wear in response to the pressures of mastication over time; therefore, it is assumed that individuals with more worn teeth are older. However, because dietary factors and paramasticatory activities can influence dental wear, such methods should only be used to estimate generalized age-at-death categories. Therefore, while Brothwell's system allocates attrition stages into five age-range categories (less than 17,17 to 25,25 to 35,35 to 45 , and $45+$ ), individuals at Bolores were divided into the more

(2) Baker, R. 1984: The Relationship of Cranial Suture Closure and Age Analyzed in a Modern Multi-racial Sample of Males and Females. MA thesis, California State University, Fullerton. general categories of Young Adult (18-25), Middle-aged Adult (25-45), and Older Adult (45+).

Because of the fragmentary condition of the Bolores material, the conventional methods of determining biological sex based upon the morphology of the os coxae (Buikstra and Ubelaker 1994; Phenice 1969) or the crania (Acsádi and Nemeskéri 1970; Buikstra and Ubelaker 1994) could not always be used. Tentative assignment of sex was based on only two or three cranial features for most individuals, and could not be confirmed by observation of pelvic morphology since none of the os coxae were directly associated with crania. However, because of sexual dimorphism, with the skeletal remains of males being, on average, more robust than those of females, in one instance a partially articulated skeleton was designated male based on upper limb measurements.

Duplicate skeletal elements, age-at-death estimations, provenance, and skeletal morphology were used to identify individuals at Bolores. Instances of pathology were evaluated on the skeletal and dental remains based on Ortner and Putschar (1985), Hillson (1996; 2005), and Mann and Hunt (2005), and scored according to criteria outlined in Buikstra and Ubelaker (1994). To assess dietary patterns, dental attrition of in situ and isolated teeth from all seasons was scored according to the 8-stage scoring system outlined in Smith (1984) (Waterman and Horwath 2009). For assessment of microwear, SEM micrographs were taken of casts and variables were coded, including the percentage of pits, scratch width in microns, scratch breadth in microns, and pit width in microns.

Analyses of stable isotope $(\mathrm{C}, \mathrm{N}, \mathrm{O}, \mathrm{Sr})$ ratios for a sample of the Bolores individuals and other burial populations in the Sizandro were conducted by Waterman for her doctoral dissertation (3). Analyses of the 2012 samples are underway and will be reported on in full in the near future. For the analysis of carbon, nitrogen, and oxygen isotopes, small bone fragments $(<5 \mathrm{~g})$ from 24 individuals (out of the 36 at Bolores) were sampled and processed by the Laboratory for Archaeological Science at the University of South Florida (Tykot 2006) (15 were from the 2012 season, and their analysis is underway). For both collagen and

(3) Vide n. 1.

Trab. prehist., 71, N. ${ }^{\circ}$ 2, julio-diciembre 2014, pp. 282-304, ISSN: 0082-5638

doi: $10.3989 /$ tp.2014.12135 
apatite results, carbon, nitrogen and oxygen isotope ratios are reported using the delta $(*)$ notation, in parts per mil (\%o) relative to the Pee Dee Belemnite (PDB) standard and Ambient Inhalable Reservoir (AIR) standards, respectively. For the analysis of strontium isotopes, dental enamel from 21 individuals was sampled (15 were from the 2012 season and their analysis is underway). All chemical processing of the enamel samples was carried out in the clean laboratory in the University of Iowa Department of Geoscience and ${ }^{87} \mathrm{Sr} /{ }^{86} \mathrm{Sr}$ ratios were measured using a $\mathrm{Nu}$ Plasma HR multicollector inductively coupled plasma-mass spectrometer (MC-ICP-MS) in the Department of Geology at the University of Illinois at Urbana-Champaign. All ratios were normalized to the NIST SRM 987 international standard value of 0.710268 .

\section{TOMB MORPHOLOGY, CHRONOLOGY, AND STRATIGRAPHY}

Bolores consists of an arched roof of soft sandstone, with a shale floor and low walls of interbedded sandstone and shale. It measures 5.6 $\mathrm{m}$ north-south by $1.7 \mathrm{~m}$ east-west, with a maximum floor-to-ceiling height of $1.5 \mathrm{~m}$ (Fig. 4). Its eastern extent is not precisely known because terrace building in 1986 encroached into the site, exposing it in profile but destroying its eastern edge. However, a reconstruction of the natural slope based on the 2007 topographic survey and soil borings suggest that the site probably did not extend more than another 1-2 $\mathrm{m}$ to the east.

Eleven AMS radiocarbon dates (Beta Analytic, Inc.) from different individuals recovered at various depths in the mortuary deposit at Bolores were obtained (Fig. 5). All the dates (with the exception of one, discussed below) cluster between 2800-2600 cal BC and indicate the site was used for a relatively short period of time. These dates also show that Bolores was contemporary with the first occupational phase at Zambujal, 2 $\mathrm{km}$ away, and could well represent one of the burial grounds for the people who lived there. One sample, from a subadult found close to the surface (0-5 cm depth), returned a date of 3530 \pm 40 b.p. (Beta 235487) (1800 cal BC). Its date appears to be sound, given that its ${ }^{13} \mathrm{C} /{ }^{12} \mathrm{C}$ ratio is not consistent with bone depletion/contamination (Ron Hatfield, personal communication

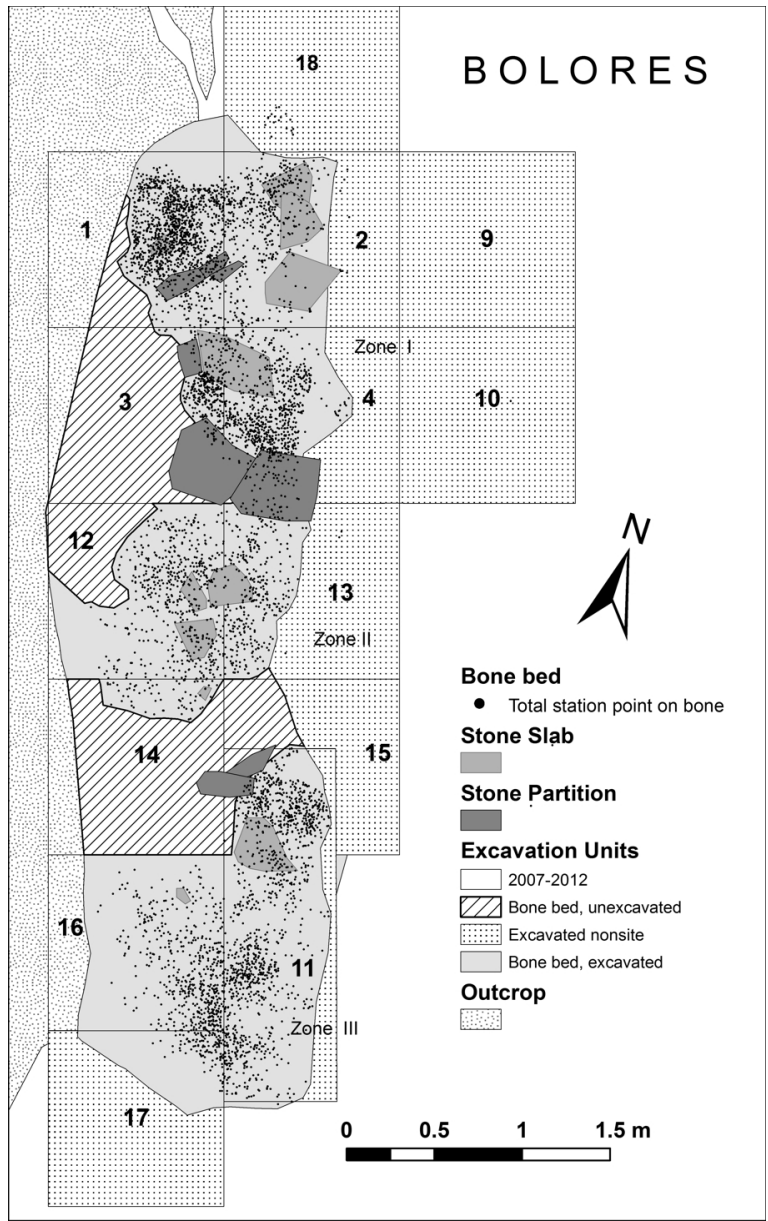

Fig. 4. Plan of the rock-cut tomb of Bolores (Torres Vedras), showing extent of bone bed, stone slabs, and stone partitions in 2012. Points denote total station points taken on bones. Some bones had more than one total station point taken on them (Joe Alan Artz).

2013). Thus, as in other Late Neolithic/Copper Age sites, it appears that an isolated $2^{\text {nd }}$ millennium BC (Early Bronze Age) individual was placed with the earlier individuals, and that even after 500-600 years, people in the region still held a memory of Bolores as a burial space.

Bolores was constructed by Late Neolithic/ Copper Age people who excavated a basin-shaped depression into layers of clayey shale and hard sandstone to create a flat shale floor, and carved an arched ceiling into overlying soft sandstone. Natural processes cannot account for the symmetry of the ceiling and walls. In addition, at its north end, the roof exhibited a series of $1 \mathrm{~cm}$ wide, rounded grooves incised into the sandstone 


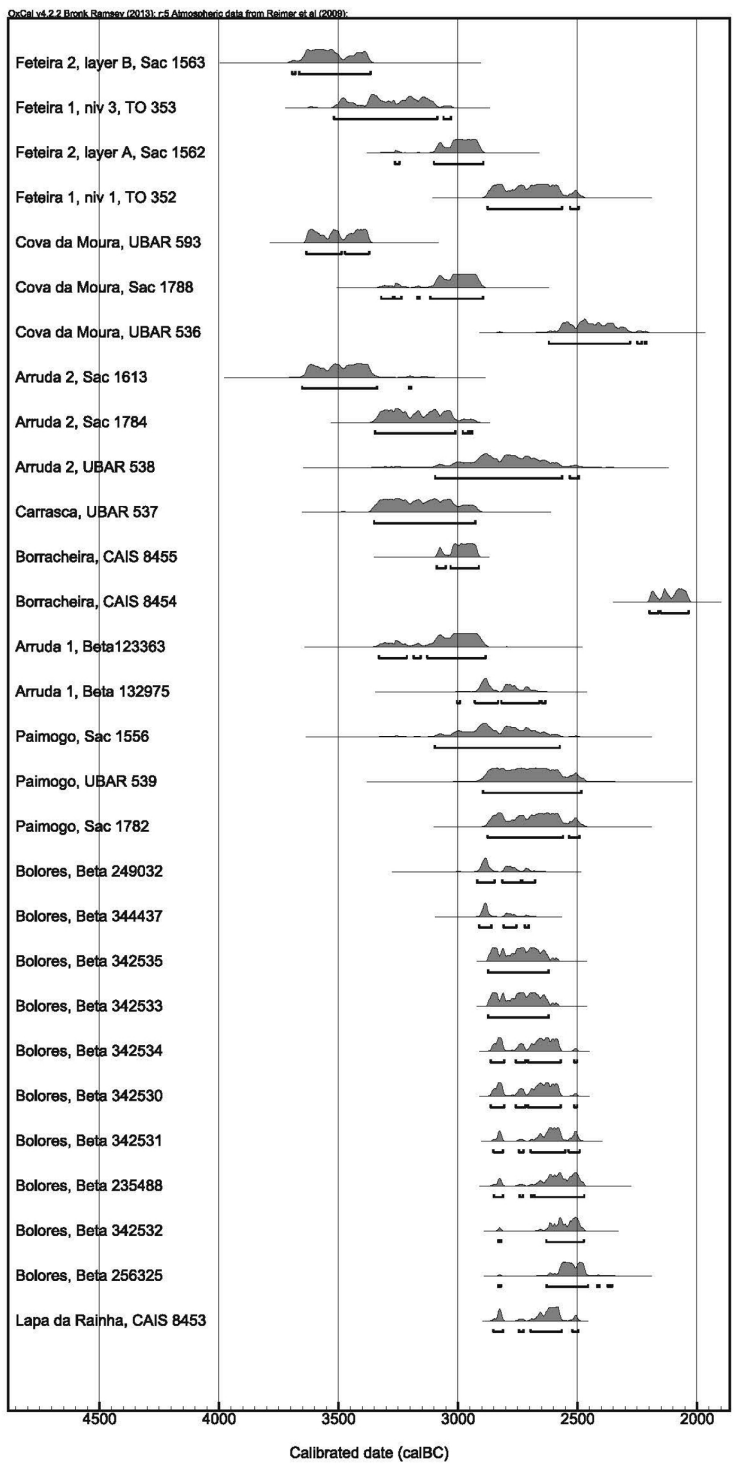

Fig. 5. Calibrated (left) and uncalibrated dates for the rock-cut tomb of Bolores (Torres Vedras) and other burials in the Torres Vedras region (all dates on human bone).

that are not the result of sedimentary bedding and are interpreted as tool marks from the carving and shaping of the roof. The size and morphology of the cave, with an excavated basin, are consistent with other sites in the Torres Vedras region, including Quinta das Lapas 1 and 2 (Monte Redondo), Casal da Lapa, Ermegeira, and Cabeço da Arruda (Ferreira 1970; Jordão and Mendes 2006/ 2007: 50).
The mortuary level is $30-40 \mathrm{~cm}$ thick and is constituted by a sandy loam matrix (Fig. 6). Much of the deposit is covered by a layer of sandstone roof collapse boulders, and no cultural material were found directly above the roof collapse layer, indicating that collapse occurred after -or perhaps even ended- the mortuary use of the site.

Within the tomb, space was partitioned and structured into three equally sized zones by large boulders and vertical and horizontal stone slabs (Fig. 4). A large sandstone boulder (roughly $40 \times 80 \times 40 \mathrm{~cm}$ ), made from a harder sandstone than the local outcrop, was found between Units 12 and 13, and Units 3 and 4. Osteological remains were recovered beneath this block, indicating that, at some point after the original use of the site, this block was put in place, perhaps to spatially segregate burials to the north and south or as an architectural roof support. In addition to this boulder, two vertically oriented sandstone slabs, approximately $40 \mathrm{~cm}$ in height, were found in Units 1 and 3. Some bones were found beneath the slabs, indicating that (as with the sandstone boulder) the latter were set up after some use of the cave. Smaller fragments of sandstone rubble and colluvium were found between the two slabs. Burials such as Bolores, with mixed features of megaliths and caves, have been termed "semi-artificial caves" or "dolmenic hypogea" (Jordão and Mendes 2006/2007).

Within the principal mortuary level and immediately above the shale bedrock, eleven slabs (most made of limestone) were recovered (Fig. 4). All are roughly aligned in a north-south line. The slabs are either trapezoidal or triangular in form and, on average, $50 \mathrm{~cm}$ in length and width. Many were covered in ochre or had ochre in the sediment (shale) beneath them. While virtually all slabs were roughly hewn on two sides, one (in Unit 2, M4) was smoothed on one face. This modification may suggest that it had a different function or use history. For example, it may have been worn down by walking over it (e.g., as a room threshold) or was a reused stela or architectural element from another site or structure. Given the local geology, those slabs made from limestone must have been brought to Bolores for the mortuary ritual. As Figure 4 illustrates, the slabs had skeletal remains closely associated with them. Cranial elements, in particular, were concentrated around the slabs, yet were generally not 


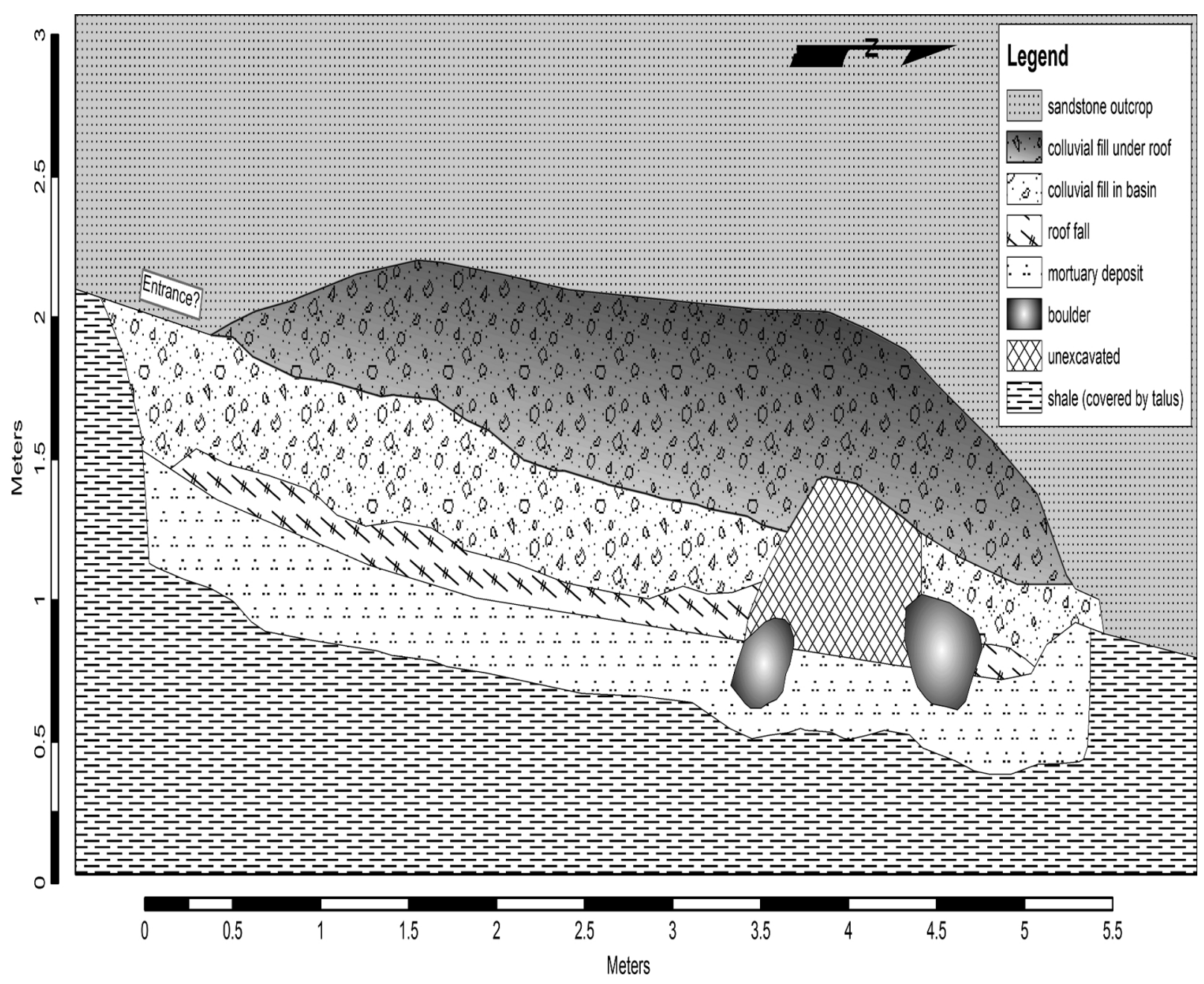

Fig. 6. Profile of the rock-cut tomb of Bolores (Torres Vedras) (Joe Alan Artz).

found directly on them (4). Comparable finds of these slabs, sometimes known as pillow stones, are rare in Iberian late prehistoric mortuary contexts. One was found at the Middle Neolithic burial of Cueva del Coquina (Granada) (Navarrete et al. 1992). The use of stone slabs as pavements within a burial chamber has been noted at other sites, such as at the artificial cave of $\mathrm{La}$ Molina (Sevilla) (Juárez Martín et al. 2010).

The original form of Bolores as a mortuary site is more difficult to reconstruct. The curvature

(4) Thies, M. and Artz, J. 2011: "GIS, taphonomy, and the artifical cave mortuary site of Bolores, Torres Vedras (Portugal)". Poster presented at the $76^{\text {th }}$ meeting of the Society for American Archaeology (Sacramento, California). of the shale bedrock in the northern and southern ends of the site, created when ancient peoples excavated out the shale, suggests that the overall plan of the mortuary space was oval. The absence of gnawmarks on, and minimal postdepositional disturbance of the human bones (as determined through refitting) also suggest that the mortuary space was enclosed. Thus, we are considering the hypothesis that, as an extension to the stone overhang, the mortuary space at Bolores was enclosed by a ring of wooden posts or a stone wall (which did not preserve). Such a form would have roughly mirrored the overall plan of a megalithic passage grave.

To assess what postdepositional processes occurred, taphonomic studies using GIS were con- 
ducted on remains recovered from the 2007 through 2010 seasons (5). These studies will be integrated to the materials found in 2012, and additional taphonomic analyses will be conducted. However, point density analyses conducted to date indicate that, overall, bone elements form clusters and different body parts tend to be grouped within the mortuary space, despite high rates of fragmentation and commingling. This may indicate secondary burials, as well as primary burials, at Bolores.

The high fragmentation of bone was undoubtedly increased by the repeated use of the site (and likely trampling of bones in pathways) and the subsequent collapse of the cave. However, differential distribution of remains by body part suggests that cultural processes involved in the secondary treatment of burials were also probably an important aspect of mortuary ritual. Future studies of bone breakage, refitting, and geospatial analyses will add details to these results.

\section{THE HUMAN POPULATION}

Despite the high level of fragmentation, we were able to identify the bone element for over $80 \%$ of the remains from the $1986-2012$ seasons (Tab. 1), which comprised elements from all body regions. While no complete skeletons were discovered, fully articulated lower limbs, upper limbs, and vertebral columns were found; five nearly complete crania with teeth were recovered in the same units. In 2012, many complete and articulated skeletal elements were recovered from Units 12 and 13. These findings suggest that primary burials did indeed occur and that commingled and fragmented remains from other regions of the site may be attributed to displacement over time by natural or anthropogenic forces.

In total, 693 human teeth were recovered at Bolores. Over 40\% of these (309/693) are permanent or deciduous teeth of subadults. Based on the maximum occurrence of upper left first incisors (26) and lower right deciduous first molars (13), with adjustments for ages-at-death according to root and crown formation and duplicate mandibular or maxillary regions, the current MNI for Bolores is 36. This count includes 13 children

(5) Vide n. 4.

\begin{tabular}{|c|c|c|c|c|c|c|}
\hline Skeletal Element & 2012 & 2010 & 2008 & 2007 & 1986 & Total \\
\hline \multicolumn{7}{|l|}{ Axial } \\
\hline Skull & 80 & 97 & 54 & 103 & 46 & 380 \\
\hline Tooth & 316 & 165 & 55 & 139 & 18 & 693 \\
\hline Hyoid & 3 & 0 & 1 & 2 & 0 & 6 \\
\hline Vertebra-indet. & 84 & 96 & 26 & 74 & 10 & 290 \\
\hline Vertebra-cervical & 41 & 36 & 8 & 46 & 5 & 136 \\
\hline Vertebra-thoracic & 28 & 30 & 10 & 43 & 10 & 121 \\
\hline Vertebra-lumbar & 24 & 7 & 10 & 26 & 4 & 71 \\
\hline Coccyx & 2 & 2 & 0 & 2 & 0 & 6 \\
\hline Sacrum & 20 & 16 & 5 & 18 & 7 & 66 \\
\hline Sternum & 4 & 7 & 2 & 10 & 1 & 24 \\
\hline Rib & 246 & 122 & 70 & 185 & 37 & 660 \\
\hline \multicolumn{7}{|l|}{ Upper Limbs } \\
\hline Clavicle & 16 & 3 & 5 & 10 & 3 & 37 \\
\hline Scapula & 30 & 9 & 3 & 16 & 3 & 61 \\
\hline Humerus & 33 & 20 & 13 & 25 & 6 & 97 \\
\hline Radius & 24 & 8 & 8 & 15 & 4 & 59 \\
\hline Ulna & 31 & 9 & 10 & 20 & 4 & 74 \\
\hline Carpal & 77 & 38 & 8 & 46 & 1 & 170 \\
\hline Metacarpal & 71 & 34 & 10 & 53 & 14 & 182 \\
\hline Phalanx-hand & 140 & 85 & 31 & 104 & 23 & 383 \\
\hline \multicolumn{7}{|l|}{ Lower Limbs } \\
\hline Pelvis & 33 & 17 & 5 & 37 & 4 & 96 \\
\hline Femur & 54 & 23 & 15 & 27 & 4 & 123 \\
\hline Patella & 14 & 5 & 0 & 11 & 1 & 31 \\
\hline Tibia & 27 & 8 & 14 & 25 & 4 & 78 \\
\hline Fibula & 27 & 10 & 6 & 10 & 4 & 57 \\
\hline Tarsal & 107 & 61 & 36 & 31 & 9 & 244 \\
\hline Metatarsal & 106 & 48 & 29 & 45 & 5 & 233 \\
\hline Sesamoid & 7 & 15 & 1 & 9 & 1 & 33 \\
\hline Phalanx-foot & 103 & 87 & 22 & 43 & 5 & 260 \\
\hline Unident. Bone & 167 & 247 & 67 & 150 & 21 & 652 \\
\hline Unident. long bone & 114 & 117 & 39 & 67 & 20 & 357 \\
\hline Phalanx-indet. & 11 & 23 & 5 & 19 & 1 & 59 \\
\hline Epiphysis & 17 & 7 & 2 & 5 & 3 & 34 \\
\hline Total & 2057 & 1452 & 570 & 1416 & 278 & 5773 \\
\hline
\end{tabular}

Tab. 1. Counts of skeletal elements from the rock-cut tomb of Bolores (Torres Vedras).

(0-10 years), 4 adolescents (10-21 years) and 19 adults. This MNI count is higher than that reported in an earlier publication, which included analyses only through the 2008 excavations (Lillios et al. 2010).

\subsection{Biological Sex}

The incomplete nature of most of the crania prevented confident assignment of sex. However, three crania were identified as possibly female based on the observation of gracile mastoid processes and sharp orbital margins. Another female

Trab. prehist., 71, N. ${ }^{\circ}$ 2, julio-diciembre 2014, pp. 282-304, ISSN: 0082-5638

doi: $10.3989 /$ tp.2014.12135 
was identified on the basis of tooth metrics. A second set of female-range teeth was recovered but could not be associated with (or excluded from) one of the gracile crania. Ten possibly male crania were identified based on one or more of the following features: robust mastoid process, blunt supra-orbital margin, prominent supra-orbital ridge, prominent mental eminence and gonial eversion. A pair of fairly complete innominates displays clearly male traits, but the relation of this pelvis to the identified individuals is unclear. The individual (Adult 1) previously identified as male based on humeral measurements (Lillios et al. 2010: 26) also exhibits a prominent mental eminence, which confirms the identification.

\subsection{Pathologies}

Skeletally visible pathology rates are low. Pathological conditions were observed on just 100 specimens. Degenerative joint disease was the most prevalent condition, with osteophytic lipping and/or erosion noted on 32 fragments. Cervical vertebrae were the most commonly affected elements $(n=9)$, followed by foot phalanges $(n=7)$ and hand phalanges $(n=4)$. Joint degeneration can be seen in young adults, often resulting from traumatic injury, but increases in frequency in older individuals. Osteophytic lipping observed on the palmar margins of nine hand phalanges may also be age-related or may be due to stress on the manual flexor muscles. Another age-related condition observed is the ossification of thyroid and costal cartilage $(n=11)$, which can occur as early as the third decade of life but increases with age (King 1939). Enthesophytes were noted at typical attachment sites including two patellae, two innominates, and one tibial tuberosity. Though often considered markers of occupational stress, enthesophytes are commonly found in older individuals.

Two conditions commonly attributed to nutritional stresses and anemia -cribra orbitalia and porotic hyperostosis - are present $(n=5)$, observed on both adult and subadult crania. Periostitis was observed on five long bone shafts, including left and right tibiae and fibulae belonging to a single individual. Inflammation of the periosteum can be caused by acute or chronic infection or by trauma. No causative injuries are apparent on these affected elements. Only three bones in the collection exhibit evidence of trauma. An extra articular facet located on a clavicle shaft suggests an unreduced dislocation. Spondylolysis, a stress fracture of the vertebral arch, was noted on a single lumbar vertebra. One proximal foot phalanx is crooked, suggesting an unset but wellhealed fracture.

The remainder of the pathologies falls into the categories of bone apposition, lytic lesions, and malformations (warping or asymmetry), largely of unknown etiology. One particularly large exostosis on the lateral surface of a fibular shaft indicates the healing of a torn ligament or muscle (Fig. 7). The only pattern recognizable in the small sample of observable pathologies is the predominance of skeletal reaction to mechanical stress and aging.

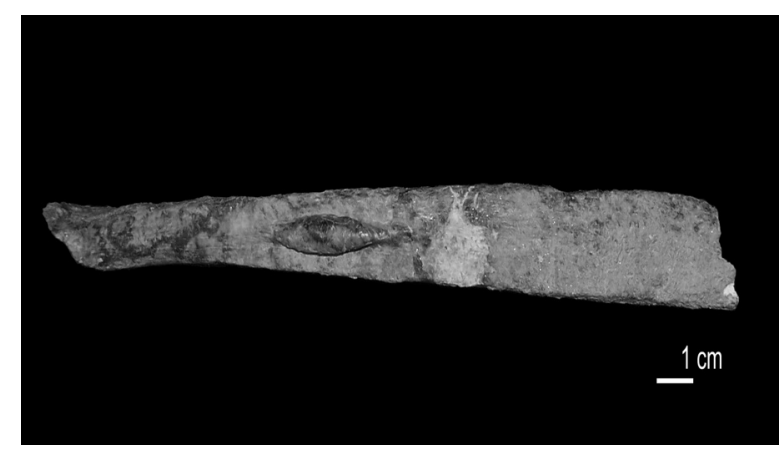

Fig. 7. Fibula with exostosis of an individual of the rockcut tomb of Bolores (Torres Vedras) (Jonathan T. Thomas).

Dental pathologies were also limited. Only 9 out of 693 teeth $(1.3 \%)$, representing 5 out of 37 individuals (13\% of the burial population), exhibit evidence of dental caries. However, there were several noted incidences of teeth lost pre-mortem that may also have been the result of carious lesions. The rate of hypoplasia is slightly higher than the caries rate, with 27 out of 693 teeth (3.9\%) exhibiting hypoplasia, and 8 out of 36 individuals ( $22 \%$ of the population) affected. For the individuals exhibiting hypoplastic defects, the time of formation appears to be variable, spanning 18 months to 5 years. Late infancy and early childhood are times in which subadults may experience physiological stresses due to weaning, 
in which a reduction in the consumption of breastmilk and the introduction of solid foods and drinking water can result in malnutrition and increased exposure to infectious diseases.

\subsection{Dental Attrition}

For those dental remains that had occlusal surfaces that could be assessed, dental attrition scores trend toward the lower end of the Smith (1984) dental attrition scale, with over 57\% $(396 / 693)$ of the teeth assigned wear scores of 1 or 2 . These low scores are most likely a reflection of the large number of subadults interred at this site. When only adult $1^{\text {st }}$ and $2^{\text {nd }}$ molars are considered, wear is more advanced, with a median score of 3.84. Only 22 teeth total wear scored a 7 or 8 on the dental attrition scale, suggesting that only a couple of older adults were present in this burial. As first reported in Waterman and Horwath (2009), wear angles were generally more pronounced in the adult molars with higher attrition scores, with a strong lingual to buccal angled slope in mandibular molars, and a strong buccal to lingual angled slope in maxillary molars. The angled wear of the more worn teeth is suggestive of a reverse curve of Monson and indicates a rather abrasive diet for the Bolores population. In several cases, asymmetrical wear on upper maxillary molars was especially pronounced, with a buccal to lingual slope of close to 40 degrees. The wear patterns on the mandibular molars, while angled, do not match the severity of the wear patterns on the maxillary ones. Maxillary central incisors also present particular attrition styles, with a strong labial to lingual angled pattern of dental wear. In the upper central incisors with the most advanced wear, the enamel was sometimes nearly or entirely missing from the lingual side of the tooth. These unique wear patterns most likely indicate that teeth were used for paramasticatory activities during the Late Neolithic/Copper Age.

\subsection{Individual Identification}

In Lillios et al. (2010), which discussed the 1986, 2007 and 2008 excavations, 6 individual adults, 6 children, and 2 adolescents were identified. By incorporating the remains from the 2010 and 2012 excavation seasons, these numbers have increased. In some cases alterations to the 2008 identifications have been made to account for new dental and skeletal element recoveries in adjacent excavation areas.

Adults and subadults were recovered in each of the three zones at Bolores (Tab. 2). In Zone I, there were 11 individuals ( 6 adults, 1 adolescent, and 4 children). In Zone II, there were 9 individuals (5 adults and 4 children). In Zone III, there were 12 individuals (4 adults, 3 adolescents, and 5 children). Four additional adults are known by isolated ULI1s, the majority found in Zone I. Given that both adults and subadults were found in all three zones, it is possible that the individuals found in each zone represent members of closely related family groups.

Adult 1 is the most skeletally complete individual recovered from Bolores. For this individual, multiple skeletal elements, including dental and post cranial remains, were found in anatomical position, representing what appears to be a tightly flexed burial with the individual buried on the left side and the head oriented to the southwest, toward the wall of the cave. As noted above, humeral measurements and the prominent mental eminence suggest that this individual was a male. Based upon the degree of occlusal attrition, Adult 1 has been classified as a middle-aged adult. The teeth of Adult 1 exhibit three dental caries, and substantial exposure of the roots indicates possible períodontal disease. Adult 1 was found in close association with a limestone slab, and within $50 \mathrm{~cm}$ of a bone handle, quartzite mace, calcite betyl, and biconical idol.

Based upon the bone and tooth formation timetables, a total of 17 adolescents or children can be distinguished. Adolescents 1 and 2 exhibit evidence of mild hypoplastic defects on at least one tooth. Infants (birth-2 years) are largely absent with the exception of Child 1 and Child 2, whose degree of dental formation suggest they died between the ages of 9 months and 2 years and 18 months and 3 years, respectively. Children 6,12 , and 13 each exhibit one instance of linear enamel hypoplasia on upper or lower canines.

\section{ISOTOPE ANALYSIS}

In order to determine the diet and mobility patterns of the Bolores population and to allow

Trab. prehist., 71, N. ${ }^{\circ}$ 2, julio-diciembre 2014, pp. 282-304, ISSN: 0082-5638

doi: $10.3989 /$ tp.2014.12135 


\begin{tabular}{|c|c|c|c|c|c|c|c|c|c|c|c|c|c|c|c|c|c|c|c|c|c|c|c|c|}
\hline 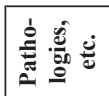 & * & & & & \pm & $\sim$ & & & - & & & $\vec{m}$ & $\begin{array}{l}n \\
f\end{array}$ & & $m$ & $\stackrel{+}{m}$ & & & & & m & & & $\stackrel{0}{i}$ \\
\hline$\dot{n}$ & 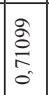 & 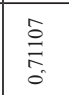 & 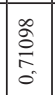 & \begin{tabular}{|l|}
0 \\
0 \\
0 \\
0 \\
0 \\
0
\end{tabular} & 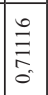 & 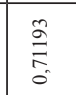 & & & $\begin{array}{l}0 \\
\stackrel{9}{Z} \\
\vdots \\
0\end{array}$ & & \begin{tabular}{l}
0 \\
\multirow{2}{*}{} \\
0 \\
0
\end{tabular} & $\begin{array}{l}0 \\
\frac{1}{0} \\
\frac{0}{2} \\
0\end{array}$ & 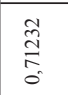 & 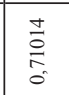 & & 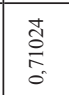 & & & & & 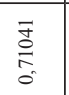 & \begin{tabular}{|l|} 
\\
\\
$\frac{0}{c}$ \\
0 \\
0
\end{tabular} & 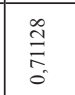 & $\begin{array}{l}\overrightarrow{0} \\
\stackrel{\overrightarrow{0}}{0} \\
0\end{array}$ \\
\hline 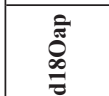 & $\begin{array}{l}0 \\
i \\
i\end{array}$ & $\stackrel{4}{4}$ & & & & & $\vec{i}$ & & & & & & & & & & $?$ & & & & ঙ্র & $m^{2}$ & & \\
\hline 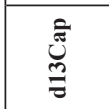 & $\mid \begin{array}{l} \pm \\
\dot{f} \\
\dot{f}\end{array}$ & $\begin{array}{l}0 \\
\stackrel{0}{+}\end{array}$ & & & & & $\frac{m}{f}$ & & & & & & & & & & $\stackrel{\partial}{\exists}$ & & & & $\begin{array}{l}0 \\
\stackrel{+}{+}\end{array}$ & जे & & \\
\hline 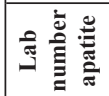 & 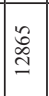 & 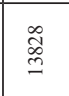 & & & & & 总 & & & & & & & & & & 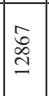 & & & & $\begin{array}{l}\infty \\
\infty \\
\stackrel{\infty}{\oplus}\end{array}$ & 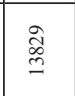 & & \\
\hline Uִ & $\dot{m}$ & $\vec{m}^{2}$ & & & & & $\circ \frac{\mathrm{g}}{\mathrm{g}}$ & & & & & & & & & & $m^{2}$ & & & & ${ }^{2}$ & $m^{2}$ & & \\
\hline 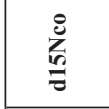 & $\infty_{0}^{\infty}$ & $\therefore$ & & & & & 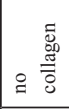 & & & & & & & & & & $a_{\infty}^{2}$ & & & & $a$ & $a^{2}$ & & \\
\hline 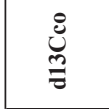 & $\mid \begin{array}{c}\infty \\
\stackrel{i}{i}\end{array}$ & $\stackrel{5}{\hat{T}}$ & & & & & 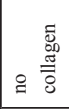 & & & & & & $\stackrel{\infty}{\rightarrow}$ & & & के & 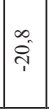 & & & & $\stackrel{0}{\circ}$ & $\frac{m}{1}$ & ิิ) & ণิ \\
\hline 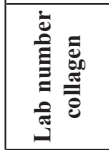 & 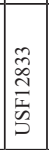 & 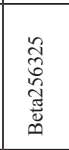 & & & & & 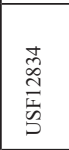 & & & & & & 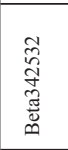 & & & 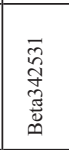 & 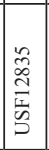 & & & & 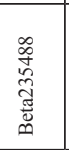 & 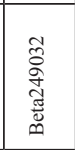 & 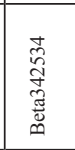 & 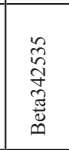 \\
\hline 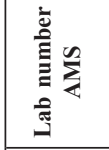 & & 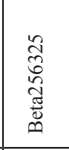 & & & & & & & & & & & 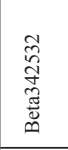 & & & 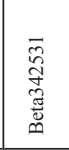 & & & & & 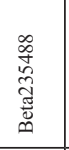 & 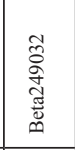 & 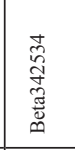 & 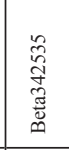 \\
\hline 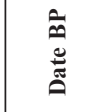 & & 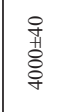 & & & & & & & & & & & $\begin{array}{l}8 \\
\text { 亲 } \\
\text { o }\end{array}$ & & & 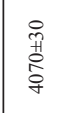 & & & & & $\begin{array}{l}\text { ơ } \\
\text { 葰 } \\
\text { ơ }\end{array}$ & $\begin{array}{l}\text { 呆 } \\
\text { 贲 } \\
\text { 子 }\end{array}$ & $\begin{array}{l}8 \\
\stackrel{0}{0} \\
\frac{0}{\sigma} \\
\frac{7}{7}\end{array}$ & $\begin{array}{l}8 \\
\stackrel{8}{+} \\
\frac{y}{7}\end{array}$ \\
\hline 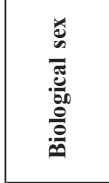 & 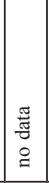 & 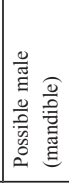 & 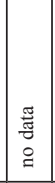 & 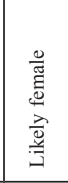 & 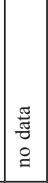 & 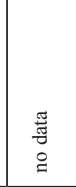 & 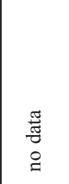 & 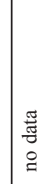 & 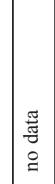 & 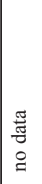 & 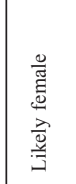 & 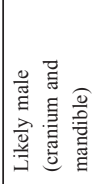 & 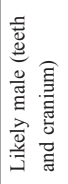 & 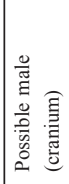 & 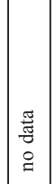 & 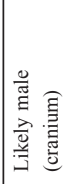 & 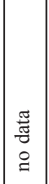 & 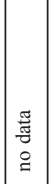 & 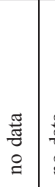 & 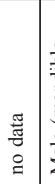 & 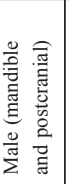 & 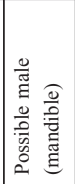 & 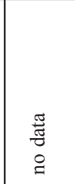 & 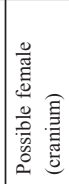 \\
\hline 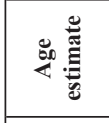 & 意 & 誓急 & 歖 & 离 & 囍 & 产 & $\begin{array}{l}\text { 䒯 } \\
\text { ठ } \\
\end{array}$ & 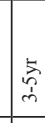 & 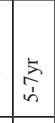 & 商 & 䔍 & 壱 & & 㲋 & & 䔍 & 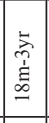 & 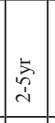 & 点 & 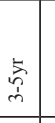 & 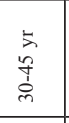 & 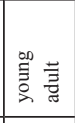 & 謍 & 壹 \\
\hline 总絪 & 䔍 & 壹 & \begin{tabular}{|l|}
$\vec{z}$ \\
\end{tabular} & 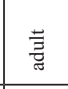 & \begin{tabular}{|l|} 
\\
䔍 \\
\end{tabular} & 言 & $\stackrel{\rho}{\overline{\bar{n}}}$ & $\fallingdotseq$ & 言 & 言 & 㶻 & 䔍 & 㶻 & 䔍 & 意 & 䔍 & $\frac{\rho}{\overline{\bar{\sigma}}}$ & 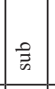 & $\overrightarrow{\bar{z}}$ & $\overline{\bar{n}}$ & 言 & 害 & 謍 & 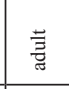 \\
\hline 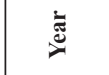 & 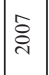 & : & 亏ัँ & ปั่ & 옴 & 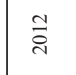 & 商 & 윰 & $\stackrel{\text { ปे }}{2}$ & 完 & 옥 & $\stackrel{\sim}{\sim}$ & ลें & 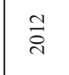 & $\stackrel{\sim}{\circ}$ & 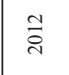 & 商 & 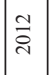 & $\stackrel{\sim}{\sim}$ & ปัँ & 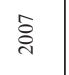 & ఫ్ర & ปั & ปั่ \\
\hline 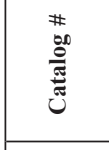 & 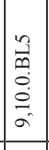 & 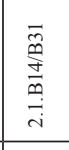 & 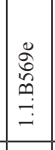 & 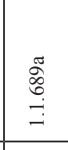 & 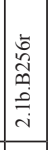 & 递 & $\underset{\substack{\infty \\
\dot{+}}}{+}$ & $\begin{array}{l}\hat{n} \\
\stackrel{\overbrace =}{\oplus}\end{array}$ & 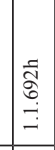 & 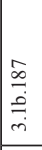 & 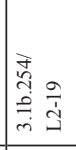 & 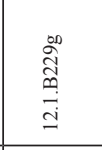 & 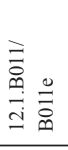 & 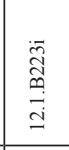 & 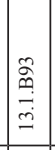 & 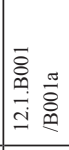 & 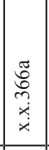 & 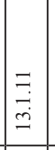 & 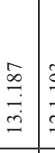 & $\begin{array}{l}\stackrel{\varrho}{=} \\
\stackrel{\underline{I}}{\mathrm{I}}\end{array}$ & 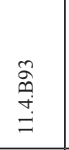 & 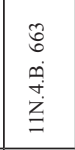 & 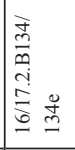 & 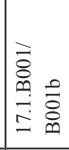 \\
\hline 芯 & - & - & - & - & - & - & - & - & - & - & - & $=$ & $=$ & $=$ & $=$ & $=$ & $=$ & $=$ & $=$ & $=$ & $\equiv$ & $\equiv$ & $\equiv$ & $\Xi$ \\
\hline 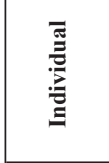 & 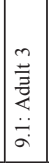 & 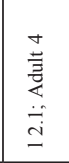 & 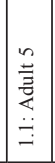 & 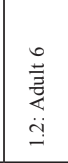 & 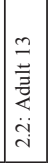 & 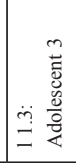 & 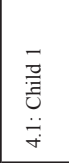 & $\begin{array}{l}n \\
\frac{z}{z} \\
\ddot{z} \\
\ddot{m}\end{array}$ & 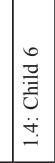 & 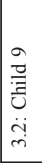 & 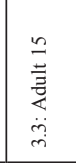 & 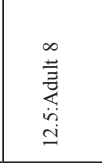 & 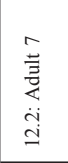 & 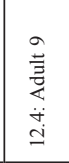 & 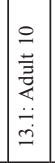 & 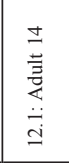 & 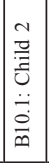 & 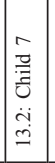 & 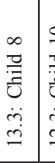 & 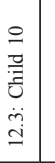 & $\begin{array}{l}\vec{\Xi} \\
\stackrel{\Xi}{\bar{z}} \\
\ddot{\Xi} \\
=\end{array}$ & 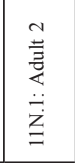 & 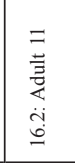 & 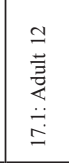 \\
\hline
\end{tabular}




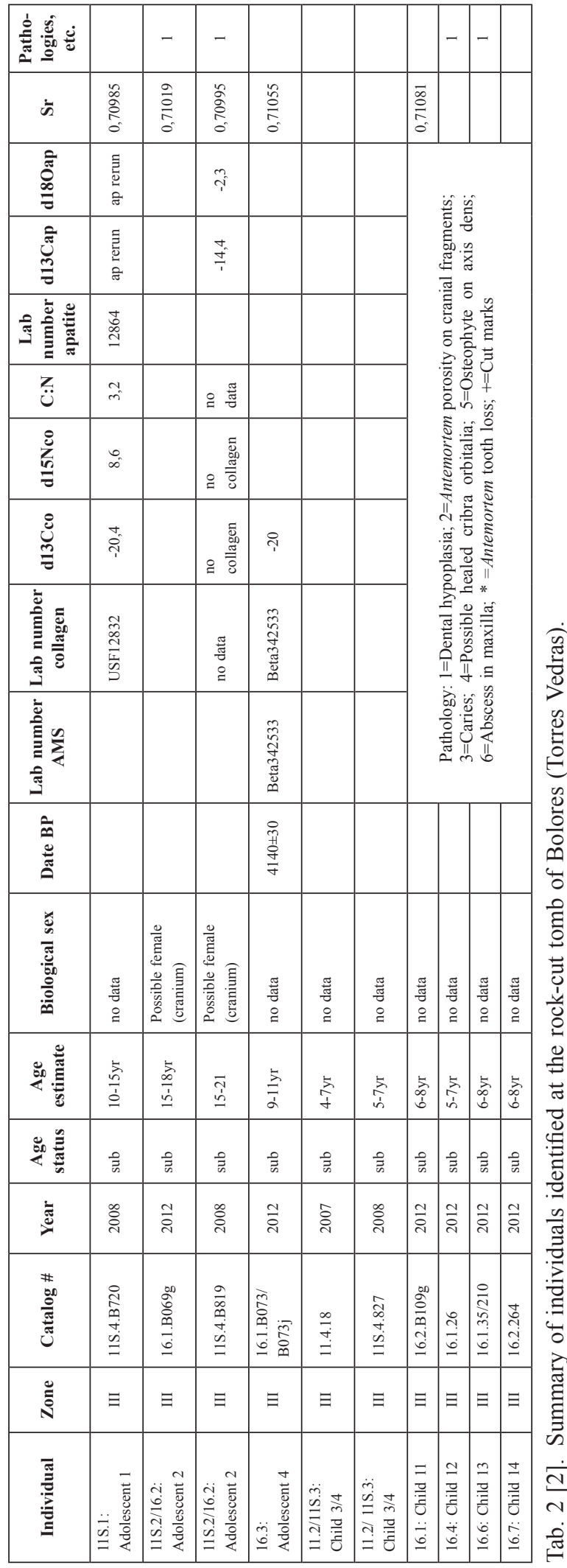

for comparison to other burial populations in the Iberian Peninsula, isotope analyses were conducted on a sample of the individuals.

\subsection{Carbon, Nitrogen and Oxygen}

Thirteen individuals recovered from the 19862010 excavation seasons have been analyzed (those from the 2012 season are in progress) (Fig. 8). Of these, three presented no viable collagen. For the remaining ten, $\delta^{13} \mathrm{C}_{\mathrm{co}}$ values ranged from a high of $-19.5 \%$ to a low of $-20.8 \%$, with a mean value of $-20.2 \pm 0.5 \%$. The $\delta^{15} \mathrm{~N}$ values ranged from a high of $9.8 \%$ to a low of $7.5 \%$, with a mean value of $8.8 \pm 0.8 \%$. Bone apatite values were acquired from eleven of the thirteen individuals. No apatite results were available for one individual due to machine error and for another because collagen results were obtained in combination with radiocarbon AMS dates and additional bone from this same individual was unavailable. Their $\delta^{13} \mathrm{C}_{\text {ap }}$ values ranged from a high of $-11.9 \%$ to a low of $-15.1 \%$, with a mean value of $-13.9 \pm 1.0 \%$. The $\delta^{18} \mathrm{O}$ values ranged from a high of $-2.0 \%$ to a low of $-3.5 \%$, with a mean value of $-2.7 \pm 0.5 \%$. The $\delta^{13} \mathrm{C}$ collagen-apatite spacing for these individuals ranged from $4.4 \%$ o $-7.9 \%$, with a mean of $5.6 \pm 1.1 \%$. The lowest collagen-apatite spacing interval belonged to the adults (4.4\%o-6.9\%o), while the highest spacing intervals were found in the subadults $(7.9 \%$ and $8.9 \%$ ).

The $\delta^{13} \mathrm{C}_{\mathrm{co}}$ and $\delta^{15} \mathrm{~N}$ values for the Bolores population reflect a diet based on terrestrial protein and $\mathrm{C}_{3}$ plants. In isotopic markers of diet, generally, a standard deviation of $0.3 \%$ or less points to populations with very homogenous diets (Lovell et al. 1986). Using this benchmark and the $\delta^{15} \mathrm{~N}$ and $\delta^{13} \mathrm{C}_{\text {ap }}$ values, protein and plant intake at Bolores were somewhat heterogeneous. Four out of the nine individuals for which $\delta^{15} \mathrm{~N}$ values were obtained were subadults. These subadults had lower $\delta^{15} \mathrm{~N}$ values than all but one of the sampled adults. Adults at Bolores tend to exhibit lower collagen-apatite spacing than the subadults. These findings suggest that there was a higher or differential protein intake for adults and may indicate culturally mediated differences in adult and subadult diets. However, it is also possible that the lower $\delta^{15} \mathrm{~N}$ values were caused by physiological differences related to bone

Trab. prehist., 71, N. ${ }^{\circ}$ 2, julio-diciembre 2014, pp. 282-304, ISSN: 0082-5638 doi: $10.3989 /$ tp.2014.12135 

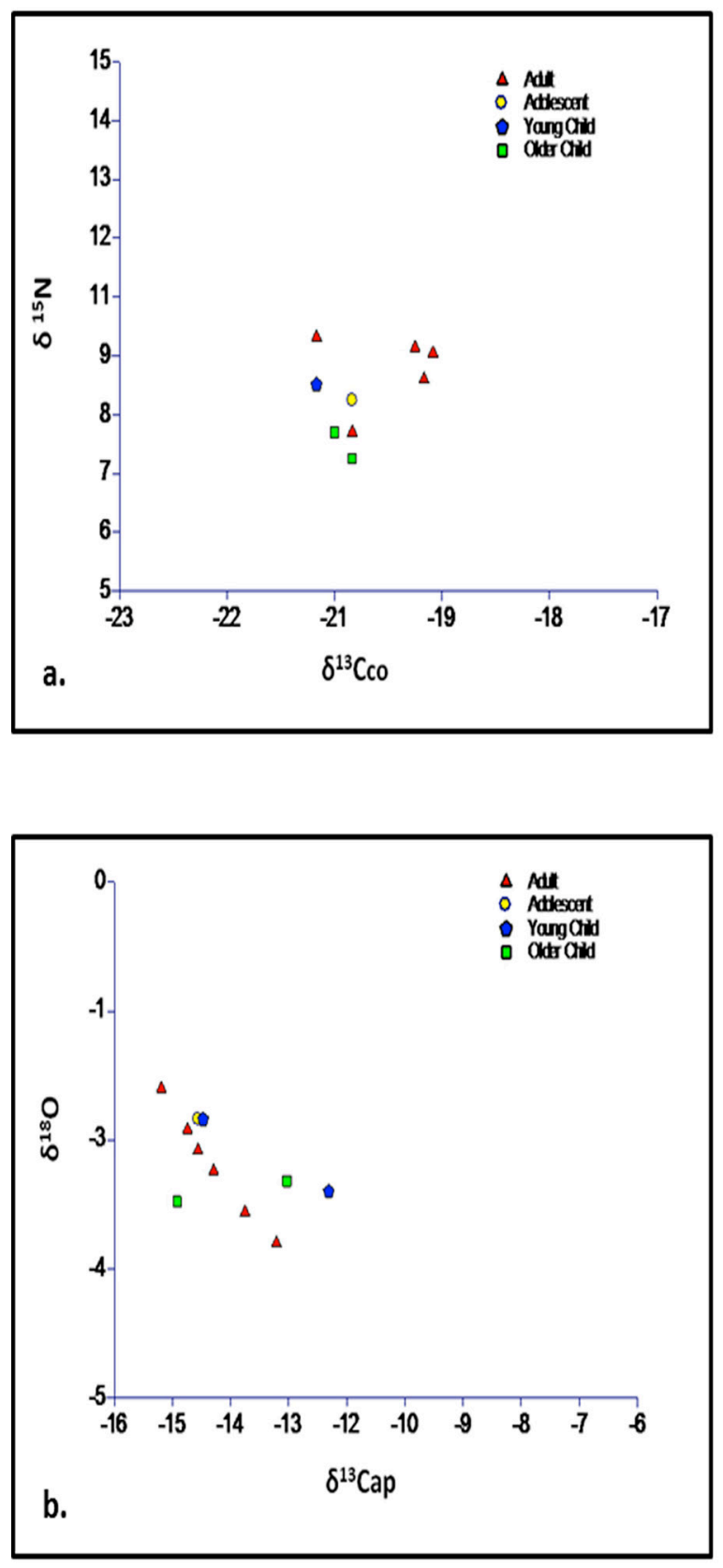

Fig. 8. a. Analysis of $\delta^{13} \mathrm{C}_{\mathrm{co}}$ and $\delta^{15} \mathrm{~N} ;$ b. $\delta^{13} \mathrm{C}_{\mathrm{ap}}$ and $\delta^{18} \mathrm{O}$ of thirteen individuals from the 1986-2010 excavation seasons at the rock-cut tomb of Bolores (Torres Vedras).

growth and development. The higher $\delta^{15} \mathrm{~N}$ values for some adults suggest an increased protein intake and/or the consumption of omnivores, such as pigs. The high $\delta^{15} \mathrm{~N}$ values in combination with slightly increased $\delta^{13} \mathrm{C}_{\mathrm{co}}$ values in Adults 1, 2 and 4 may indicate some consumption of marine foods for these individuals; but, in general there is little evidence that aquatic resources were a major source of protein.

The subadult with the highest $\delta^{15} \mathrm{~N}$ value $(8.9 \%$ ) was the youngest child sampled (Child 2 ). It is likely that this value reflects the consumption of breast milk. In addition to the high $\delta^{15} \mathrm{~N}$ value, Child 2 also exhibits an enrichment of its $\delta^{13} \mathrm{C}_{\text {ap }}$ values and a slight enrichment of its $\delta^{18} \mathrm{O}$ values, which likely reflect isotope fractionation from the consumption of breast milk. In general, the low standard deviations in $\delta^{18} \mathrm{O}$ values for the rest of the sampled individuals suggest similar water sources for the Bolores population.

\subsection{Strontium}

Geologically, southern Portugal is diverse, with pockets of Cretaceous, Jurassic, and Triassic sediments near the coast and Palaeozoic Hercynian basement metamorphic and granitic rocks in the interior (Pawlewicz et al. 1997). This heterogeneous landscape makes it possible to trace coastal and inland movements of humans and animals based upon analysis of bioavailable strontium isotopes ratios. A study of strontium isotopes ratios, ${ }^{87} \mathrm{Sr} /{ }^{86} \mathrm{Sr}$, was recently completed in the Estremadura which included human samples from Bolores (Waterman et al. 2014) (6). In this study the local bioavailable ${ }^{87} \mathrm{Sr} /{ }^{86} \mathrm{Sr}$ composition for the surveyed region (roughly $25 \mathrm{~km}^{2}$ ) was defined as $0.7090-0.7115$ (plus or minus $2 \sigma$ from the sample mean) based upon the ratio ranges of humans sampled from several burials in the region surrounding Bolores.

For the six individuals sampled from Bolores, the ${ }^{87} \mathrm{Sr} /{ }^{86} \mathrm{Sr}$ ratios ranged from 0.709850 to 0.710987 , with a mean of $0.710397 \pm 0.000523$ (Tab. 2). The subadults had the lowest ratios, although the difference was not significant. Based upon the defined local range, none of the individuals have been identified as migrants from the interior or any region with a distinctly different geological substrate.

(6) Vide n. 1. 


\section{FUNERARY RITUALS}

The material traces of ritual practices are evident at Bolores in the placement of slabs with the bodies, the deposition of ochre, and offerings made of ceramic, stone, bone, and shell (Fig. 9). While some of these practices appear throughout the site, such as the slabs and ochre, others show more spatial differentiation, suggesting that there were some social distinctions of the individuals buried. Specifically, small pieces of ochre (red and yellow) and red coloration derived from ochre were found beneath and on top of the stone slabs, on the bones, and in the soil matrix surrounding the bodies throughout the site. Analyses are underway to determine if the ochre is differentially associated with certain bone elements, age, or sex classes of individuals.

In contrast, artifacts are not consistently found throughout the site (Fig. 9). Artifacts, particularly

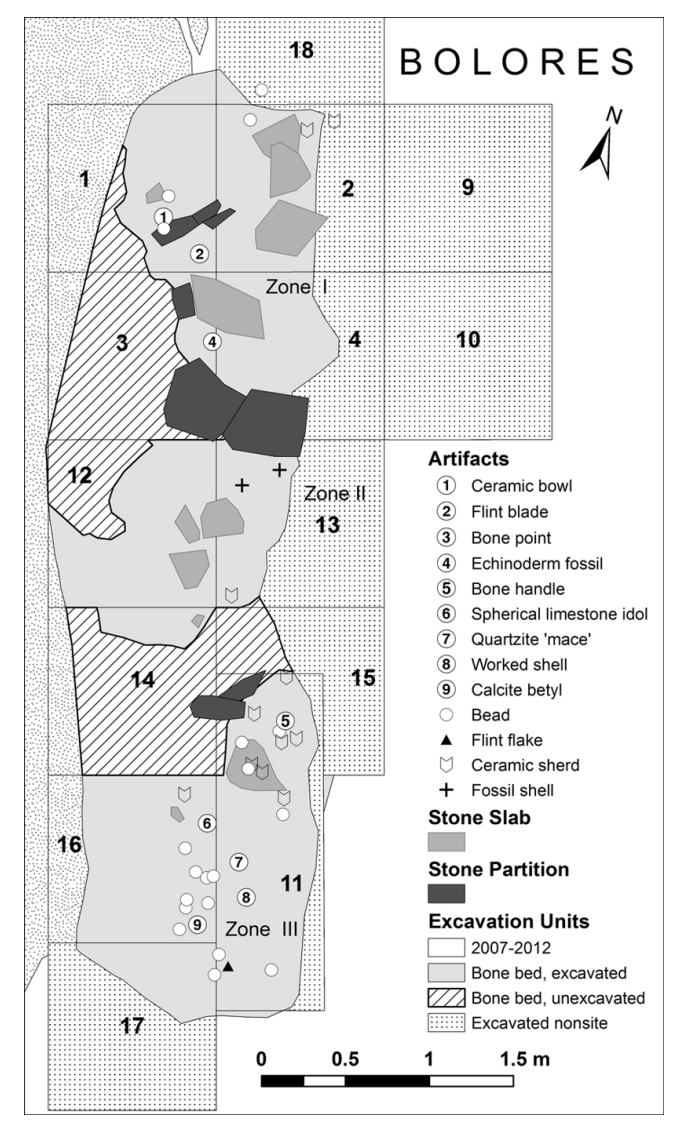

Fig. 9. Plan of the rock-cut tomb of Bolores (Torres Vedras), through 2012 season, showing artifacts, stone slabs, and stone partitions (Joe Alan Artz). beads, are overwhelmingly found in the southern $1 / 3$ of the site (Zone III-in Units 11, 16, and 17, south of the stone partition in Unit 11). In the northern $1 / 3$ of the site (Zone I-north of the stone partition in Units 3 and 4), some beads and the two flint blades were found. However, in the central zone (Zone II), between these two stone partitions and in Units 12 and 13, artifacts were rare; only two ceramic fragments and two fossil shells were found.

Surprisingly, ceramics were infrequent at the site, as a whole. Approximately 50 ceramic sherds and one complete bowl were recovered. Two basic vessel forms are represented (Fig. 10). The most common are small (15 $\mathrm{cm}$ diameter) open bowls; more rare are larger, closed form jars. A similar range of vessel forms was found at Cova da Moura (Spindler 1981). The complete bowl was found in Unit 1 in 2012, in association with an adult cranium. It measures $7.8 \mathrm{~cm}$ in diameter, $4 \mathrm{~cm}$ in height, and.50 cm in thickness; when excavated, it contained bone fragments and sediment. These sediments were found to primarily contain ochre, as well as small bones and charcoal, which were too small for identification (Laura Crawford, personal communication 2013).

In addition to ceramics, some lithics were recovered. Two flint blades were found, both in Zone I. One (BOL.63, length: $10.0 \mathrm{~cm}$ ) has retouch along one edge. The second (BOL.3.1.L1; length: $9.0 \mathrm{~cm}$ ) has retouch along both edges. An Olympus BX51 optical microscope with magnification capacities between 50x and 400x was used to record microwear from use and hafting

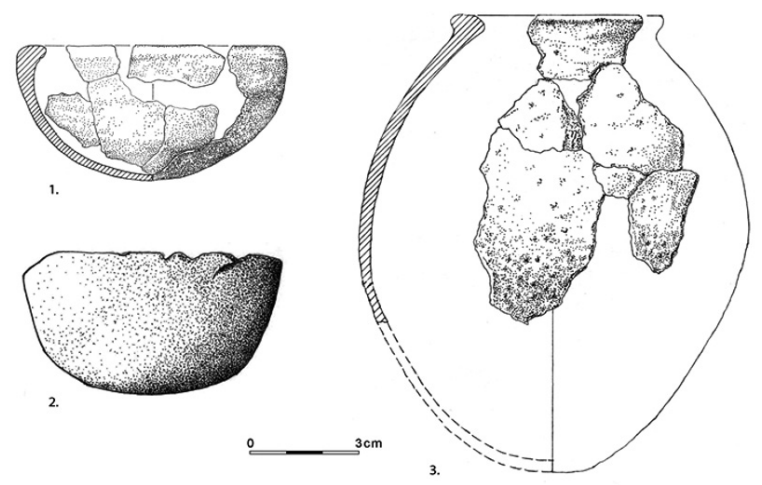

Fig. 10. Ceramics from the rock-cut tomb of Bolores (Torres Vedras): 1. and 2. Open bowls (BOL.1/2/5/21 and BOL.1.1.C1.), 3. Jar (BOL.3/8/ 0). Drawings 1, 3 Guida Casella, and 2 Leonel Trindade. 
on this second blade (Melanie Pope, personal communication 2012). It was found to have extensive use polish on both the dorsal and ventral faces of one edge, which also exhibits sheen visible to the naked eye (sickle polish). The polish attributes are consistent with those produced experimentally from cutting cereal grasses. Polish traces on the edge opposing the use-edge are most likely the result of hafting, either in a wood or bone/antler handle.

All the unusual objects -which one might term idols or at least items of unknown functionwere found in Zone III. A mace-like object, made from a quartzite cobble with a pecked groove around its midsection, was recovered in association with Adult 1 (Fig. 11). It is $6.5 \mathrm{~cm}$ in diameter and weighs $345 \mathrm{~g}$. Other than the groove, the surface of the object is smooth and presents no evidence of wear or percussion. Comparable objects have been reported in the Portuguese Estremadura from the burial sites of Cabeço da Arruda 1 (Torres Vedras) and Palmela (hipogeu 2), as well as the settlements of Pedrão (Early Copper Age level) and Leceia (Level C. 2, Calcolítico Pleno) (Soares 2003: 89). Near this, a biconical limestone object was recovered, also in close proximity $(<50 \mathrm{~cm})$ to Adult 1 (Fig. 12). This object, with a wavy groove around its circumference and a 1-cm-deep hole at its base, has its closest parallels with the pine idols (idolos pinho) of the Estremadura (Almagro Gorbea 1973). However, there are enough differences between the Bolores idol's form and design and the idolos pinho to suggest they should be considered typologically distinct. The third unusual object, found near the spherical idol, was a 6-cm-long calcite betyl (Fig. 13). Square in cross-section and $3 \mathrm{~cm}$ thick, the object was polished on all surfaces. The crystal is translucent and has natural discolorations in angled bands. Its non-local origin and translucent quality rendered it, no doubt, a symbolically potent object. Similar betyls made of limestone were found at Poço Velho (Cascais) (Gonçalves 2008: Fig. 2.241). A similar object made on translucent stone was found at the Copper Age settlement site of La Orden-Seminario, in Huelva, Spain (Vera Rodríguez et al. 2010: 235, Plate XIX). This betyl is significantly longer than the one from Bolores (at $15.3 \mathrm{~cm}$ ), and somewhat different in form (tronco-conical).

Two other ritual items were recovered, but as they were found prior to our excavations, their
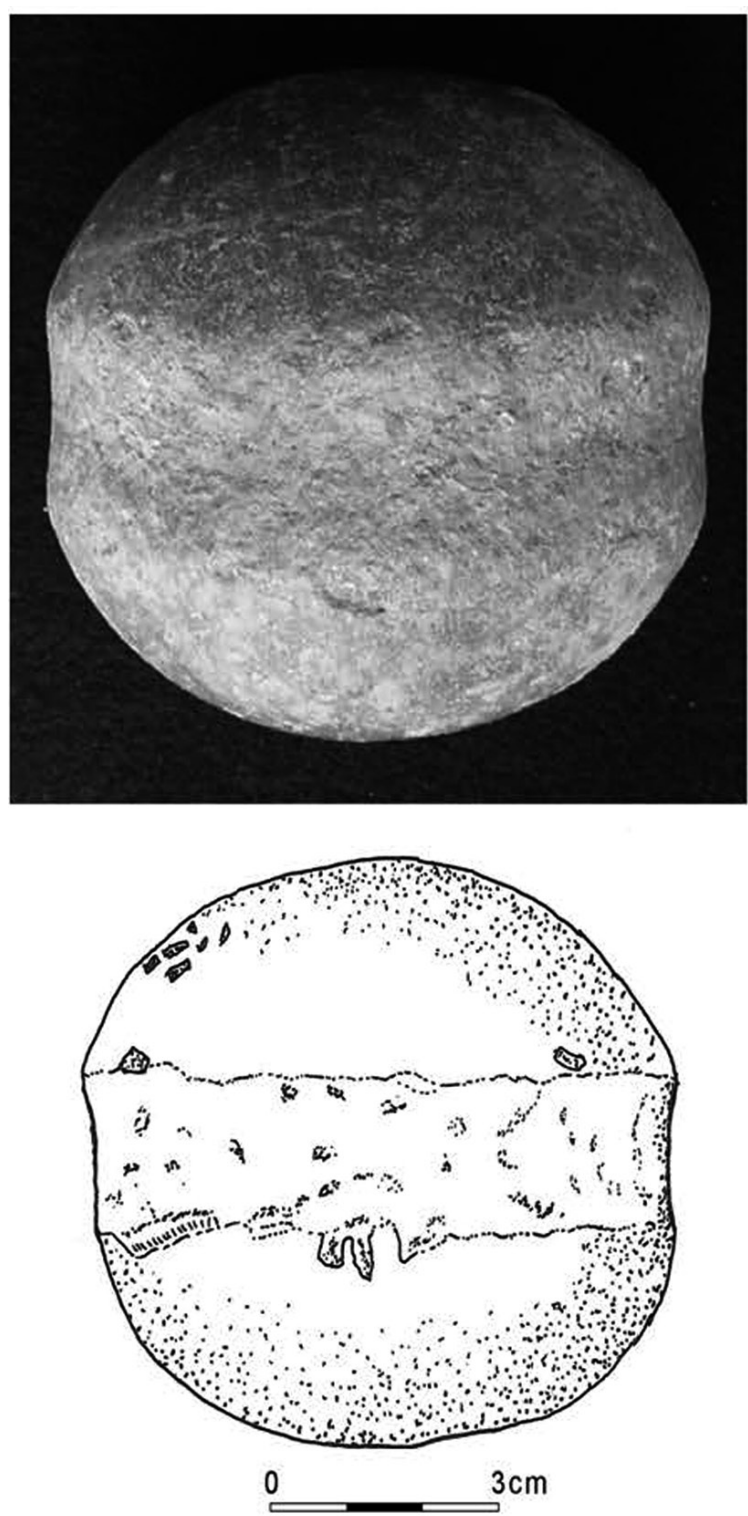

Fig. 11. Quartzite 'mace' with a pecked groove around its midsection (BOL.11.1.M507) from the rock-cut tomb of Bolores (Torres Vedras). Drawing Claire Tolmie 2011.

precise context is unknown. These include a limestone cylinder, which was found by the landowners around 1975 (Kunst and Trindade 1990: Tafel 4). It measures $10 \mathrm{~cm}$ in length and $5 \mathrm{~cm}$ in diameter. Comparable cylinders were found at Monte Abraão, Alapraia, and Palmela (Leisner 1965). At around the same time as the limestone cylinder, a fragment of a carved and curved object made of limestone (which looks like a bacu- 


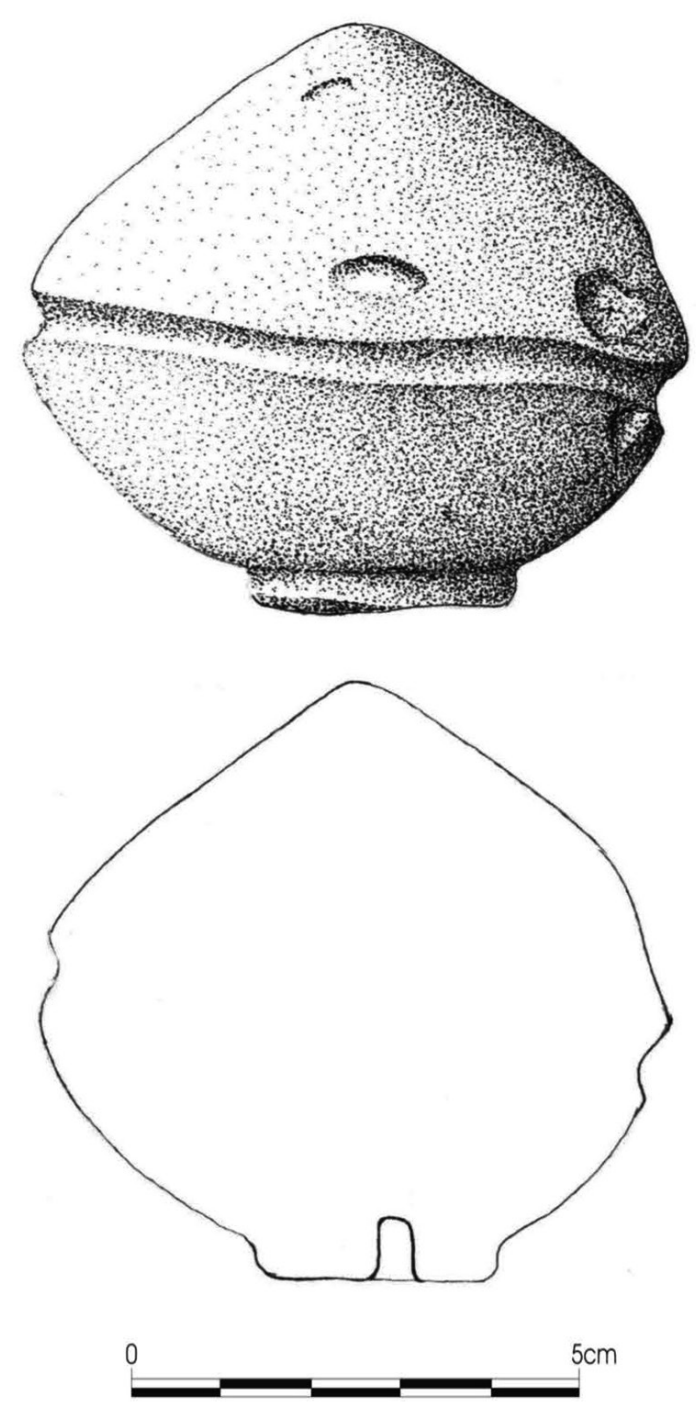

Fig. 12. Limestone biconical idol (BOL.16.2.M5) from the rock-cut tomb of Bolores (Torres Vedras). Drawing Leonel Trindade 2012.

lum), $8 \mathrm{~cm}$ long, was also found (Kunst and Trindade 1990: Tafel 4). It is a curious object, and its original form is uncertain.

Twenty three beads were recovered at Bolores, and all but 4 were found in Zone III. The majority are flat, disc-shaped shell and limestone beads, common throughout the Estremadura. Because shell and limestone are chemically similar and because they share similar physical properties, differentiating these materials was not always possible in instances where shell growth rings were not visible with microscopy. Both
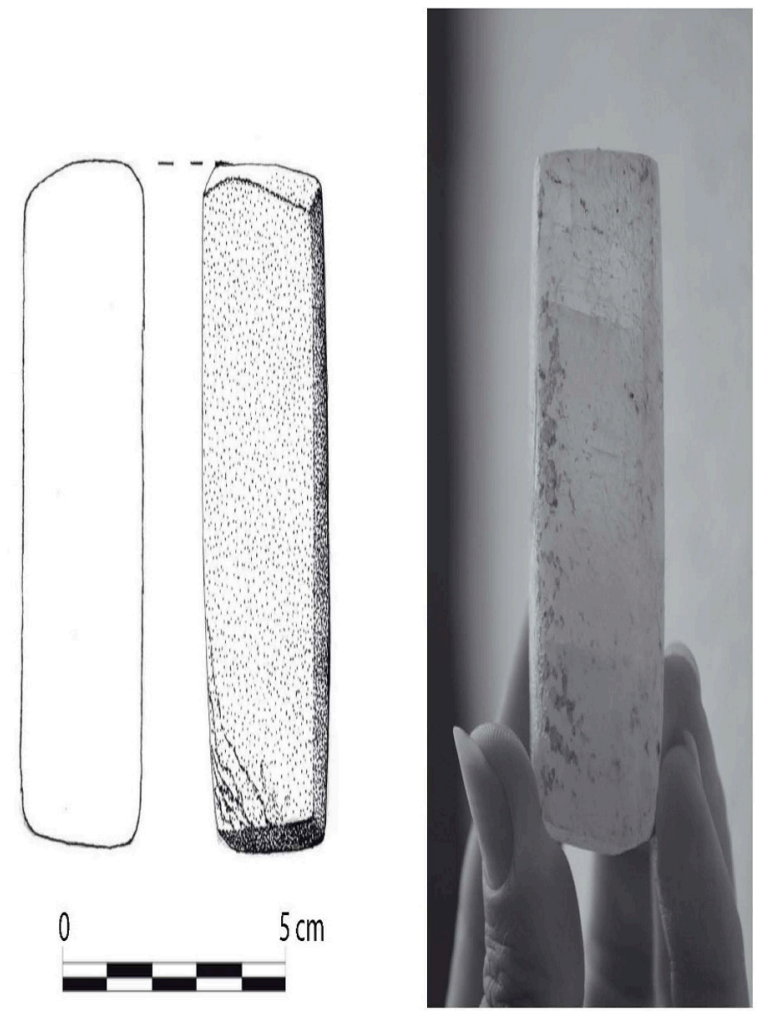

Fig. 13. Calcite betyl (BOL.16.2.M8) from the rock-cut tomb of Bolores (Torres Vedras). Left: Drawing by Leonel Trindade 2012. Right: Photograph by Katina Lillios.

shell and limestone are, however, locally available raw materials. Approximately $25 \%$ are a dark grey stone (likely slate). All are discoidal, with an average diameter of $4.9 \mathrm{~mm}$ (standard deviation $=0.8 \mathrm{~mm}$ ), an average thickness of $2.4 \mathrm{~mm}$ (s.d. $=.8 \mathrm{~mm}$ ), and an average perforation width of $1.7 \mathrm{~mm}$ (s.d. $=.3 \mathrm{~mm}$ ). Low standard deviations such as these likely resulted from batch production, raw material properties, and technological choices or traditions. Virtually all were biconically perforated using a flint drill and show little or no evidence of usewear under microscopy. Given the concentration of beads in the Zone III, it may be that an individual or individuals buried in this area was or were distinctive, or of a higher status than those elsewhere in the site. Given the rich bead assemblages of other burials in Torres Vedras (Cova da Moura = 1474, Cabeço da Arruda II $=217$, Paimogo $=306$ ) (Thomas 2011: 34), the low number of beads found at Bolores is atypical. 
In addition to the ceramics, lithics, and beads, two bone artifacts were recovered. Two conjoining fragments of a worked bone point were found. Conjoined, the object is $3.0 \mathrm{~cm}$ long; its diameter is $0.5 \mathrm{~cm}$ along its body and $0.3 \mathrm{~cm}$ at its narrower, worked end. It was broken at some time in the distant past, as mineralization is evident on the fracture surfaces of both fragments. Evidence for working in the form of striations can be seen under the microscope, at the narrow tip. Its function is indeterminate, but its morphology and size are comparable to worked bone artifacts from the settlement of Pragança (Salvado 2004: Est. LXII). In addition, a bone handle for a knife or other tool, measuring $6.5 \mathrm{~cm}$ long and $1 \mathrm{~cm}$ in diameter, and broken in two pieces, was recovered. It was made from the distal end of a sheep tibia. Two small perforations are present at one end, which may have been for decoration or to attach cordage; its surface has a polished appearance, likely resulting from extensive use prior to burial. Similar bone handles were recovered at Zambujal (Sangmeister and Schubart 1981: tafel 59i, k; tafel 63).

Finally, an echinoderm fossil was found. Whether it represents an intrusive find from the shale bedrock or an item placed with the dead is difficult to ascertain. It is known, however, that fossils (such as crinoids) were fashioned into artifacts, such as beads, in the Late Neolithic/Copper Age (Thomas 2011).

\section{DISCUSSION}

The architecture, material culture, human population of Bolores present features comparable to other Late Neolithic/Copper Age burial sites in the Portuguese Estremadura, as noted, but also some interesting distinctions.

Tombs carved into the bedrock -most often limestone, but also sandstone- were widely used as mortuary spaces during the Late Neolithic/ Copper Age throughout southern Iberia (Rivero Galán 1988). Most, like Bolores, also open to the east. However, Bolores is somewhat distinctive in that it presents architectural features that render it a typological hybrid. That is, it has megalithic qualities; large stone blocks were brought in to spatially structure the use of the site, as well as incorporate the use of stone slabs to structure the space within the burial chamber. Given the labor involved to construct the site, it is useful to consider why an existing burial was not used, such as Cova da Moura, located some $5 \mathrm{~km}$ away. That Bolores was constructed despite local alternatives that did not require labor to construct suggests that someone or some people wanted to create a distinction or to assert some difference with these other groups.

Much of the material culture found at Bolores is similar to that found at other contemporary burials (ceramics, limestone cylinders, flint blades), but there are also items that are rather distinctive (quartzite 'mace', limestone idol). This may suggest that this burial population included people with a social identity distinctive from other groups. The spatial segregation of individuals within the burial into three zones separated by stone partitions and clustered around different slabs may also point to socially significant subgroupings. The concentration of material culture -including beads and idols in Zone III- is particularly intriguing. Future analyses of dental morphology to assess biological affinity are in progress and will assess whether these clusters correspond to biological groupings.

In terms of its general demographic profile, Bolores shares many similarities with contemporary populations in the Estremadura (Tab. 3). With the exception of neonates, all age ranges are represented, and childhood mortality was high. The incidence of chronic bone-affecting disease is relatively low, as is the incidence of caries and evidence for traumatic death. The low pathology rates combined with the high rates of mortality for children and young adults may indicate that that this sample is exhibiting signs of the osteological paradox (Wood et al. 1992), in which individuals die before signs of disease can accumulate on the skeleton and, thereby, appear to represent a generally healthy population. Thus, we may be seeing signs that people at this time were dying of acute rather than chronic diseases. Also like other contemporary populations, the sample from Bolores exhibits little variation in $\delta^{13} \mathrm{C}_{\mathrm{co}}$. These values are influenced by the types of proteins consumed, suggesting that marine and terrestrial protein intake was fairly similar among members of the community buried at the site (7). Additionally, both the $\delta^{18} \mathrm{O}$ values and ${ }^{87} \mathrm{Sr} /{ }^{86} \mathrm{Sr}$

\section{(7) Vide n. 1.}




\begin{tabular}{|c|c|c|c|c|c|c|c|c|c|c|c|c|c|c|c|c|c|c|}
\hline$\stackrel{\triangleq}{\circ}$ & $\bar{z}$ & 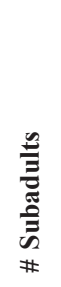 & 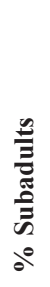 & 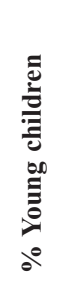 & 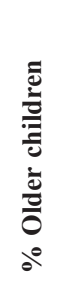 & 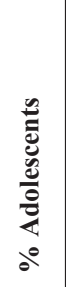 & 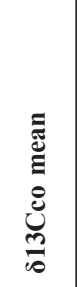 & 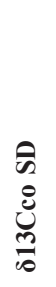 & 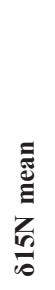 & $\begin{array}{l}\text { 命 } \\
\frac{Z}{\infty} \\
\frac{\pi}{0}\end{array}$ & 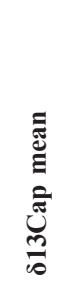 & 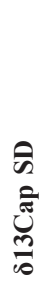 & 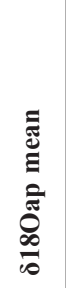 & $\begin{array}{l}\text { के } \\
\text { है } \\
0 \\
\frac{\infty}{0}\end{array}$ & 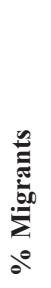 & 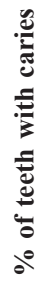 & 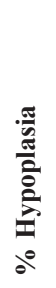 & 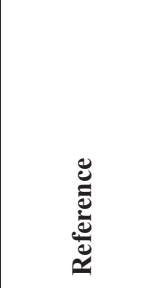 \\
\hline Bolores & 36 & 17 & 47 & 16,7 & 19,4 & 11,1 & $-20,2$ & 0,5 & 8,8 & 0,9 & $-14,3$ & 0,9 & $-2,6$ & 0,7 & 0 & 1,3 & 3,0 & this work \\
\hline $\begin{array}{l}\text { Cova da } \\
\text { Moura }\end{array}$ & 90 & 15 & 17 & 5,6 & 7,8 & 3,3 & $-20,0$ & 0,6 & 9,4 & 0,9 & $-11,2$ & 1,2 & $-2,8$ & 0,3 & 30 & 8,2 & 1,4 & Silva 2003 \\
\hline Feteira II & 68 & 26 & 38 & 10,3 & 23,5 & 4,4 & $-20,2$ & 0,3 & 8,2 & 0,5 & $-12,7$ & 1,2 & $-2,6$ & 1,0 & 0 & 8,5 & 7,4 & $\begin{array}{l}\text { Waterman } \\
2006 \\
\text { (footnote 9) }\end{array}$ \\
\hline Paimogo I & 413 & 123 & 30 & 11,5 & 10 & 7,9 & $-20,2$ & 0,5 & 8,5 & 0,8 & $-13,0$ & 0,7 & $-2,2$ & 0,4 & 0 & 6,7 & 1,0 & Silva 2003 \\
\hline $\begin{array}{l}\text { Cabeço da } \\
\text { Arruda I }\end{array}$ & 19 & 5 & 26 & 5,3 & 10,5 & 10,5 & $-19,9$ & 0,3 & 8,6 & 0,6 & $-13,7$ & 0,4 & $-2,4$ & 0,5 & 10 & 5,7 & 5,3 & Silva 2003 \\
\hline $\begin{array}{l}\text { Lapa da } \\
\text { Rainha II }\end{array}$ & 6 & 2 & 33 & 16,7 & 16,7 & 0 & $-19,6$ & 0,2 & 8,9 & 0,8 & $-13,6$ & 0,4 & $-2,8$ & 0,2 & 0 & 6,9 & 3,4 & $\begin{array}{l}\text { Waterman } \\
2012 \\
\text { (footnote 1) }\end{array}$ \\
\hline $\begin{array}{l}\text { Tholos da } \\
\text { Borracheira }\end{array}$ & 6 & 3 & 50 & 16,7 & 33,3 & 0 & $-20,0$ & 0,3 & 8,1 & 0,8 & $-13,1$ & 1,4 & $-3,3$ & 0,8 & 0 & 7,7 & 0,0 & $\begin{array}{l}\text { Waterman } \\
2012 \\
\text { (footnote 1) }\end{array}$ \\
\hline
\end{tabular}

Tab. 3. Rock-cut tomb of Bolores population compared to other burial populations in the region.

ratios indicate that these individuals were all local to the area.

The individuals buried at Bolores do, however, show some distinctions from contemporary burial populations in their diet. Several Late Neolithic/Copper Age burials in the region were found to house individuals with significantly enriched $\delta^{13} \mathrm{C}_{\mathrm{ap}}$ values without corresponding enriched $\delta^{13} \mathrm{C}_{\mathrm{co}}$ values - signaling access to $\mathrm{C}_{4}$ or CAM plants (8) (Ambrose et al. 1997). The Bolores population does not evidence access to these plants. With the exception of possibly seaweed, few native $\mathrm{C}_{4}$ or CAM plants are known in the region that would have been exploited by humans. The early introduction of millet (Panicum miliaceum) could explain this dietary signature, but there is little evidence of its widespread use in human diets or as a fodder crop. Generally, it is believed that millet was not introduced in Portugal until the Early Iron Age (Pinto da Silva 1988; Rovira Buendía 2007). With regard to the $\delta^{13} C_{a p}$ values and temporal aspects of the surveyed burials, the two sites with the strongest evidence of $\mathrm{C}_{4}$ or CAM plants intake, Cova da

(8) Vide n. 1.
Moura and Feteira II (9), have earlier dates than Bolores. If the $\delta^{13} C_{a p}$ values are evidence for the early introduction of millet, it seems odd that its use is more prevalent in these earlier sites. In contrast, if the enriched $\delta^{13} \mathrm{Cap}$ values were attributable to a native plant in the estuary environment and/or seaweed, its absence from the diet in later burial populations may be explained by environmental and cultural changes in food consumption and production activities during the Late Neolithic/Copper Age. As there is strong evidence for the degradation of the estuary environment between the $4^{\text {th }}-2^{\text {nd }}$ millennia BC (Dambeck et al. 2010), it may be that native $C_{4}$ or CAM plants became less obtainable. Alternatively, these enriched $\delta^{13} \mathrm{C}_{\text {ap }}$ values may be related to diagenic alterations in the bone apatite due to burial conditions.

Overall, the people buried at Bolores were a local population similar to other neighboring groups, but who, nevertheless, show some differences from these populations in terms of their

(9) Waterman, A. J. 2006: Health Status in Prehistoric Portugal: Dental Pathology and Childhood Mortality Patterns from the Late Neolithic burials of Feteira (Lourinhã). MA thesis, University of Iowa, Iowa City.

Trab. prehist., 71, N. $^{\circ} 2$, julio-diciembre 2014 , pp. 282-304, ISSN: 0082-5638 doi: $10.3989 /$ tp.2014.12135 
dietary signatures, material culture, and architecture used to bury them. Furthermore, there appears to have been some distinctions made amongst the individuals at Bolores, denoted spatially and through material culture, as well as some dietary differences between the young and old. These distinctions, however, do not suggest an underclass of individuals consistent with a state model.

\section{ACKNOWLEDGMENTS}

The National Science Foundation (\#1153568) and the University of Iowa provided financial support for this project. Natália Antunes and Paula Torres permitted us to excavate on their family's property. The Câmara Municipal de Torres Vedras, especially Carlos Anunciação, Ana Umbelino, Francisca Ramos, Rui Silva, and Rui Brás provided logistical and crew support. Andre Mano and Bruno Silva Camilo of the Associação Leonel Trindade permitted us the use of their laboratory. Our project has also benefited from input provided by Michael Kunst, Ana-Monica Racila, Guida Casella, Rui Boaventura, Robert Franciscus, Joel Irish, Filipa Neto, Cidália Duarte, Primitiva Bueno Ramírez, Leonardo García Sanjuán, John Willman, Robert Tykot, and João Zilhão.

\section{BIBLIOGRAPHY}

Acsádi, G. W. and Nemeskéri, J. 1970: History of the Human Life Span and Mortality. Akadémiai Kiadó. Budapest.

AlQahtani, S. J.; Hector, M. P. and Liversidge, H. M. 2010: "Brief communication: the London atlas of human tooth development and eruption". American Journal of Physical Anthropology 142: 481-490.

Almagro Gorbea, M. J. 1973: Los ídolos del Bronce I Hispánico. Bibliotheca Praehistorica Hispana XII, CSIC. Madrid.

Ambrose, S. H., Butler, B. M., Hanson, D. B., HunterAnderson, R. L., and Krueger, H. W. 1997: "Stable isotopic analysis of human diet in the Marianas Archipelago, Western Pacific". American Journal of Physical Anthropology,104 (3): 343-361.

Anonymous 1991: "Serviços Geologicos de Portugal". Carta Geológica de Portugal 1:500,000. Lisbon, 5. ${ }^{\mathrm{a}}$ edição.
Baker, B. J.; Dupras, T. K. and Tocheri, M. W. 2005: The Osteology of Infants and Children. Texas A \& M University Press. College Station, Texas.

Belo, A. R.; Trindade, L. and Ferreira, O. da Veiga 1961: "A gruta da Cova da Moura (Torres Vedras)". Comunicações dos Serviços Geológicos de Portugal 45: 391-418.

Bronk Ramsey, C. 2013: OxCal 4.2.2. http://c14.arch. ox.ac.uk/oxcal

Brooks, S. T. and Suchey, J. M. 1990: "Skeletal age determination based on the os pubis: a comparison of the Acsádi-Nemeskéri and Suchey-Brooks methods". Journal of Human Evolution and Human Behavior 5: 227-238.

Brothwell, D. R. 1981: Digging up Bones. Cornell University Press. Ithaca.

Buikstra, J. and Ubelaker, D. (eds.) 1994: Standards for Data Collection from Human Skeletal Remains: Proceedings of a Seminar at the Field Museum of Natural History. Arkansas Archeological Survey. Fayetteville.

Dabrio, C. J.; Zazo, C.; Goy, J. L.; Sierro, F. J.; Borja, F.; Lario, J.; González, J. A. andFlores, J. A. 2000: "Depositional history of estuarine infill during the last postglacial transgression (Gulf of Cadiz, Southern Spain)". Marine Geology 162: 381-404.

Dabrio, C. J.; Zazo, C.; Lario, J.; Goy, J. L.; Sierro, F. J.; Borja, F.; Gonzalez, J. A., and Flores, J. A. 1999: "Sequence stratigraphy of Holocene incised-valley fills and coastal evolution in the Gulf of Cadiz (southern Spain)". Geologie en Mijnbouw 77 (3-4): 263-281.

Dambeck, R.; Thiemeyer, H.; Herrmann, N.; Joop Kalis, A.; Kunst, M.; Lord, A.; Rittweger, H.; Stika, H. P. and Stobbe, A. 2010: "Holozäne Talentwicklung und Landschaftswandel am Rio Sizandro. Geoarchäologische Beiträge zum 'Projekt Sizandro-Alcabrichel' (Portugal)". Madrider Mitteilungen 51: 9-46.

Dias, J. M. A.; Boski, T.; Rodrigues, A. and Magalhães, F. 2000: "Coast line evolution in Portugal since the Last Glacial Maximum until present -a synthesis". Marine Geology 170: 177-186.

Ferreira, O. da Veiga. 1970: "Grutas artificiais da Quinta das Lapas (Torres Vedras)". Junta Distrital de Lisboa, Boletim Cultural 73/74: 177-187.

Ferreira, O. da Veiga and Trindade, L. 1955: “A necrópole do Cabeço da Arruda (Torres Vedras)". Anais da Faculdade de Ciências do Porto 38 (3): 193212.

Gallay, G.; Spindler, K.; Trindade, L. and Ferreira, O. da Veiga 1973: O monumento préhistórico de Pai Mogo (Lourinhã). Associação dos Arqueólogos Portugueses. Lisbon.

Gonçalves, V. dos S. 2008: As ocupações pré-históricas das furnas do Poço Velho, Cascais. Câmara Municipal de Cascais. Cascais. 
Hillson, S. 1996: Dental Anthropology. Cambridge University Press. Cambridge.

Hillson, S. 2005: Teeth. Cambridge University Press. Cambridge.

Hoffman, G. 1990: "Zur holozänen Landschaftsentwicklung im Tal des Rio Sizandro (Portugal)". Madrider Mitteilungen 31: 21-33.

Hoffman, G. and Schulz, H. D. 1995: "Cambio de situación de la línea costera y estratigrafía del Holoceno en el Valle del Río Sizandro/Portugal". In M. Kunst (ed.): Origens, Estruturas e Relações das Culturas Calcoliticas da Península Ibérica. Actas das Ias Jornadas Arqueológicas de Torres Vedras (Torres Vedras 1987): 45-46. Lisboa.

Jordão, P. and Mendes, P. 2006/2007: "As grutas artificiais da Estremadura portuguesa: uma leitura crítica das arquitecturas". Arqueologia e História 58/59: 43-78.

Juárez Martín, J. M.; Moreno, E.; Cáceres, P.; Lacalle, R.; Guijo, J. M.; Nieto, J. M.; Aguilar, J. A. and Rico, E. 2010: El enterramiento en cueva artificial de La Molina (Lora de Estepa, Sevilla). Arqueología monografías, Consejería de Cultura, Junta de Andalucía. Sevilla.

King, J. B. 1939: "Calcification of the costal cartilages”. British Journal of Radiology 12 (133): 2-12.

Kunst, M. 2007: “Zambujal (Torres Vedras, Lisboa): Relatório das escavações de 2001". Revista Portuguesa de Arqueologia 10 (1): 95-118.

Kunst, M. and Lutz, N. 2008: "Zambujal (Torres Vedras, Portugal). Zur Präzision der absoluten Chronologie durch die Untersuchungen an der vierten Befestigungslinie". Madrider Mitteilungen 49: 2963.

Kunst, M. and Trindade, L. 1990: "Zur Besiedlungesgeschicte des Sizandrotals: Ergebnisse aus der Küstenforschung". Madrider Mitteilungen 31: 3483.

Kunst, M. and Uerpmann, H. P. 1996: "Zambujal (Portugal). Vorbericht über die grabungen 1994". Madrider Mitteilungen 37: 10-36.

Kunst, M. and Uerpmann, H. P. 2002: "Zambujal (Torres Vedras, Lisboa). Relatório das escavações de 1994 e 1995". Revista Portuguesa de Arqueologia 5: 67-120.

Leisner, V. 1965: Die Megalithgräber der Iberischen Halbinsel, Der Westen. Madrider Forschungen 1, 3. Walter de Gruyter. Berlín.

Lillios, K. T.; Waterman, A. J.; Artz, J. A. and Josephs, R. L. 2010: "The Neolithic-Early Bronze Age mortuary rockshelter of Bolores, Torres Vedras, Portugal: Results from the 2007 and 2008 excavations". Journal of Field Archaeology 35 (1): 19-39.

Lord, A.; Cabral, M. C.; Dambeck, R. and Kunst, M. 2010: "Ostracod evidence for the Neolithic environment of Rio Sizandro, Portugal". Palaeobiodiversity and Palaeoenvironments 91 (3): 1-14.
Lovejoy, C. O.; Meindl, R. S.; Pryzbeck, T. R. and Mensforth, R. P. 1985: "Chronological metamorphosis of the auricular surface of the ilium: a new method for the determination of adult skeletal age at death". American Journal of Physical Anthropology 68 (1): 15-28.

Lovell, N. C.; Nelson, D. E. and Schwarcz, H. P. 1986: "Carbon isotope ratios in palaeodiet: lack of age or sex effect". Archaeometry 28 (1): 51-55.

Lull, V. 1983: La cultura de El Argar. Un modelo para el estudio de las formaciones económico-sociales prehistóricas. Akal. Madrid.

Mann, R. and Hunt, D. 2005: Photographic Regional Atlas of Bone Disease: A Guide to Pathologic and Normal Variation in the Human Skeleton. Charles C. Thomas Publisher Ltd. Springfield, Illinois.

Mann, R.; Symes, S. A.; and Bass, W. A. 1987: "Maxillary sutures obliteration: aging the human skeleton based on intact or fragmentary maxilla". Journal of Forensic Sciences 32: 148-157.

Meindl, R. and Lovejoy, C. O. 1985: "Ectocranial suture closure: a revised method for the determination of skeletal age at death based on the lateral-anterior sutures". American Journal of Physical Anthropology 68: 57-66.

Meindl, R. S. and Lovejoy, C. O. 1989: "Age changes in the pelvis: implications for palaeodemography". In M.Y. Iscan (ed.): Age Markers in the Human Skeleton. Charles C. Thomas. Springfield, IL: 137168.

Navarrete, M. S.; Carrasco, J. and Gamiz, J. 1992: La Cueva del Coquino (Loja-Granada). Monografías del Servicio de Investigación y Promoción Patrimonial, Excmo. Ayuntamiento de Loja. Loja.

Nocete Calvo, F. 1989: El Espacio de la Coerción. La Transición al Estado en las Campiñas del Alto Guadalquivir (España). British Archaeological Reports International Series 492, Archaeopress. Oxford.

Ortner, D. J. and Putschar, W. G. H. 1985: Identification of Pathological Conditions in Human Skeletal Remains. Smithsonian Institution Press. Washington, D.C.

Pawlewicz, M. J.; Steinshouer, D. W. and Gautier, D. L. 1997: Map Showing Geology, Oil and Gas Fields, and Geologic Provinces of Europe including Turkey. Open File Report 97-470I. Central Region Energy Resources Team, U.S. Department of the Interior, U.S. Geological Survey.

Phenice, T. W. 1969: “A newly developed visual method of sexing in the os pubis". American Journal of Physical Anthropology 30: 297-301.

Pinto da Silva, A. R. 1988: “A paleoetnobotánica na arqueologia portuguesa. Resultados desde 1931 a 1987'. En F. Queiroga, I. M. Sousa and C. M. Oliveira (eds.): Actas do Encontro 'Paleoecologia e

Trab. prehist., 71, N. ${ }^{\circ}$ 2, julio-diciembre 2014, pp. 282-304, ISSN: 0082-5638

doi: $10.3989 /$ tp. 2014.12135 
Arqueologia' (Vila Nova de Famalicão 1988): 5-49. Vila Nova de Famalicão.

Reimer, P. J., Baillie, M. G. L., Bard, E., Bayliss, A., Beck, J. W., Blackwell, P. G., Bronk Ramsey, C., Buck, C. E., Burr, G. S., Edwards, R. L., Friedrich, M., Grootes, P. M., Guilderson, T. P., Hajdas, I., Heaton, T. J., Hogg, A. G., Hughen, K. A., Kaiser, K. F., Kromer, B., McCormac, F. G., Manning, S. W., Reimer, R. W., Richards, D. A., Southon, J. R., Talamo, S., Turney, C. S. M., van der Plicht, J., and Weyhenmeyer, C. E. 2009: "IntCal09 and Marine09 radiocarbon age calibration curves, 0-50,000 years cal BP". Radiocarbon 51(4): 1111-1150.

Rivero Galán, E. 1988: Análisis de las cuevas artificiales en Andalucía y Portugal. Universidad de Sevilla. Sevilla.

Rovira Buendía, N. 2007: Agricultura y gestión de los recursos vegetales en el sureste de la península ibérica durante la prehistoria reciente. Tesis doctoral. Universitat Pompeu Fabra. Barcelona. http://www.tdx.cat/handle/10803/7468 (access 30VI-2014).

Salvado, M. C. B. R. da Silva. 2004: Apontamentos sobre a utilização do osso no Neolítico e Calcolítico da Península de Lisboa. Suplemento 2, O Arqueólogo Português. Lisbon.

Sangmeister, E. and Schubart, H. 1981: Zambujal. Die Grabungen 1964 bis 1973. Phillip von Zabern. Mainz am Rhein.

Sangmeister, E.; Schubart, H. and Trindade, L. 1969: "Escavações no castro eneolíticodo Zambujal 1966". O Arqueólogo Português III, 3: 71-114.

Sangmeister, E.; Schubart, H. and Trindade, L. 1970: "Escavações na fortificação eneolítica do Zambujal. 1968”. O Arqueólogo Português III, 4: 65-114.

Sangmeister, E.; Schubart, H. and Trindade, L. 1971: "Escavações na fortificação da idade do cobre do Zambujal. Portugal, 1970". O Arqueólogo Português III, 5: 51-96.

Sangmeister, E.; Schubart, H. and Trindade, L. 19741977: "Escavações na fortificação da idade do cobre do Zambujal. Portugal, 1972-1973”. O Arqueólogo Português III, 7-9: 125-140.

Scheuer, L. and Black, S. 2000: Developmental Juvenile Osteology. Academic Press. San Diego, California.

Schour, I. and Massler, M. 1941: "The development of the human dentition". Journal of the American Dental Association 28: 1153-1160.

Silva, A. M. 2003: "Portuguese populations of Late Neolithic and Chalcolithic periods exhumed from collective burials: an overview". Anthropologie XLI/1-2: 55-64.

Smith, B. H. 1984: "Patterns of molar wear in hunter-gatherers and agriculturalists". American Journal of Physical Anthropology 63 (1): 39-56.
Smith, B. H. 1991: "Standards of human tooth formation and dental age assessment". In M. A. Kelley and C. S. Larsen (ed.): Advances in Dental Anthropology. Wiley-Liss. New York: 143-168.

Soares, J. 2003: Os hipogeus pré-históricos da Quinta do Anjo (Palmela) e as economias do simbólico. Museu da Arqueologia e Etnografia do Distrito de Setúbal. Setúbal.

Spindler, K. 1981: Cova da Moura-Die Besiedlung des Atlantischen Küstengebietes Mittelportugals vom Neolithikum bis an das Ende der Bronzezeit. Madrider Beiträge 7, Zabern-Verlag. Mainz.

Spindler, K. and Trindade, L. 1970: "A póvoa eneolitica do Penedo (Torres Vedras)". Actas das Ias Jornadas Arqueológicas-Lisboa (Lisboa 1969): 57191. Lisbon.

Thomas, J. T. 2011: "Fashioning identities, forging inequalities: Late Neolithic/Copper Age personal ornaments of the Portuguese Estremadura". European Journal of Archaeology 14 (1-2): 29-59.

Todd, T. W. 1920: "Age changes in the pubic bone, 1. The male white pubis". American Journal of Physical Anthropology 3: 285-339.

Todd, T. W. 1921: "Age changes in the pubic bone, 2. The pubis of the male Negro-White hybrid". American Journal of Physical Anthropology 4: 1-26.

Todd, T. W. and Lyon, D. W. Jr. 1925a: "Cranial suture closure. Its progress and age relationship. Part II. Ectocranial closure in adult males of white stock". American Journal of Physical Anthropology 8 (1): 23-45.

Todd, T. W. and Lyon, D. W. Jr. 1925b: "Cranial suture closure. Part III. Endocranial closure in adult males of Negro stock". American Journal of Physical Anthropology 8: 44-71.

Todd, T. W. and Lyon, D. W. Jr. 1925c: "Suture closure. Part IV. Ectocranial closure in adult males of negro stock". American Journal of Physical Anthropology 8: 149-168.

Torres, M. A. M. 1861: Descripção historica e economica da villa e termo de Torres-Vedras: parte histórica. Imprensa da Universidade. Coimbra.

Trindade, L. and Ferreira, O. da Veiga 1963: "Sepultura pré-histórica de Serra da Vila (T. Vedras)". Revista da Guimarães 73 (1/2): 83-89.

Tykot, R. H. 2006: "Isotope analyses and the histories of maize". In J. E. Staller, R. H. Tykot and B. F. Benz: Histories of Maize: Multidisciplinary Approaches to the Prehistory, Linguistics, Biogeography, Domestication, and Evolution of Maize. New York, 131-142.

Ubelaker, D. H. 1999: Human skeletal remains. Excavation, Analysis, Interpretation. Taraxacum. Washington, DC.

Uerpmann, H. and Uerpmann, M. 2003: Zambujal: Die stein und beinartefakteausden grabungen 1964 
bis 1973. Madrider Beiträge 5, Zambujal Teil 4. Philip von Zabern. Mainz am Rhein.

Vera Rodríguez, J. C.; Linares Catela, J. A.; Armenteros Lojo, M. J. and González Batanero, D. 2010: "Depósitos de ídolos en el poblado de La Orden-Seminario de Huelva: espacios rituales en contexto habitacional". In C. Cacho, R. Maicas, E. Galan and J. A. Martos (eds.): Los ojos que nunca se cierran. Ídolos en las primeras sociedades campesinas (16 diciembre 2009). DVD Diseño gráfico e interactivo Raúl Areces. Museo Arqueológico Nacional, Ministerio de Cultura. Madrid: 199-242. http://www.man. es/man/dms/man/estudio/publicaciones/conferencias-congresos/MAN-2009-Ojos-cierran/MAN-Con2009-Ojos-cierran.pdf (accessed 23-VI-2014).

Vis, G. J.; Kasse, C. and Vandenberghe, J. 2008: "Late Pleistocene and Holocene palaeogeography of the Lower Tagus Valley (Portugal): effects of relative sea level, valley morphology and sediment supply". Quaternary Science Reviews 27: 1682-1709.

Waterman, A. J. and Horwath, B. 2009: "Dental attrition patterns in two late prehistoric skeletal col- lections from the Estremadura region of Portugal: comparisons and results". American Journal of Physical Anthropology 138 (S48): 267.

Waterman, A. J.; Peate, D. W.; Silva, A. M. and Thomas, J. T. 2014: "In Search of Homelands: Using Strontium Isotopes to Identify Biological Markers of Mobility in Late Prehistoric Portugal". Journal of Archaeological Science 42: 119-127.

White, T. D. 2000: Human Osteology. Academic Press. San Diego.

Wood, J. W.; Milner, G. R.; Harpending, H. C and Weiss K. M. 1992: "The osteological paradox: problems of inferring prehistoric health from skeletal samples". Current Anthropology 33(4): 343-370.

Zazo, C.; Goy, J. L.; Lario, J. and Silva, P. G. 1996: "Littoral zone and rapid climatic changes during the last 20,000 years. The Iberian study case". Zeitschrift für Geomorphologie, Suppl.-Bd.102: 119-134.

Zilhão, J. 1987: "Bolóres (Torres Vedras)". Informação Arqueológica 8: 54-55. 